\title{
19. Yüzyıldan 20. Yüzyıla Doğu Akdeniz Liman Kentlerinde Kentsel Mekân: Patras, Volos ve Mersin Üzerinden Bir Inceleme*
}

\author{
Tülin Selvi Ünlü** \\ Emel Göksu*** \\ Özet
}

19. yüzyıldan 20. yüzyıl başına kadarki dönem, yalnızca Akdeniz coğrafyası için değil, tüm dünya için, kapitalist ilişkilerle şekillenen yeni bir ekonomi ile başta iktisadi alanda olmak üzere pek çok alanda yapısal değişimlerin yaşandığ süreçte, liman kentleri ve özellikle de Doğu Akdeniz liman kentleri, küresel kapitalist bütünleşmenin mekânları haline gelmiştir. Ancak, üst ölçekteki benzer koşullar söz konusu kentler için bir "ortak kader çizgisi" oluştursa da yerelin kendine özgü koşullarında gelişen ya da ortaya çıkan bu kentler, denizle kurdukları ilişkiyle özgün kentsel yapılar olarak daima dikkat çekmişlerdir. Bu çalışmada, Doğu Akdeniz liman kentlerinin, uluslararası ticaret ve dolayısıyla farklı kültürlerin birlikteliğiyle şekillenen kentsel yaşamı ve kendine özgü kentsel mekânı, onu üreten ve farklılaştıran dinamikler bağlamında ele alınacaktır. Böylece, "söz konusu kentleri, birer 'liman kenti' olarak adlandırmamızı sağlayan nedir?" sorusuna yanıt aranırken, öte yandan kendine özgü koşulları ile Akdeniz'in doğusundaki liman kentlerinin, ortaya çıkıp gelişmelerinde etkili olan benzer koşul ve süreçlere karşın, ne tür farklılıklar ve/ya benzerlikler taşıdıkları, üç Doğu Akdeniz liman kenti Patras, Volos ve Mersin üzerinden tartışılacaktır. Söz konusu soru ve tartışmanın, mekânsal yapı ve biçimleniş süreci temelinde bir "Doğu Akdeniz liman kenti" karakterinin varlığını sorgulama olanağı sunması hedeflenmektedir.

Anahtar sözcükler: Doğu Akdeniz liman kenti, kent kimliği, Patras, Volos, Mersin

\section{Abstract \\ Urban Space in Eastern Mediterranean Port-cities from 19th Century to 20th Century: An Investigation Through Patras, Volos, and Mersin}

The period between the 19th and the beginning of 20th century has been an era during which structural changes have taken place, not only for the Mediterranean geography but for the whole world, in various fields, beginning with the economic field with a new economy taking shape with capitalist relations. During this process, port-cities, and especially Eastern Mediterranean port-cities have been sites of global capitalist integration. Nevertheless, whereas similar conditions in the upper scale have created "a common fate" for the cities in question, these cities that have sprung or developed under the distinctive conditions of the locality have always stood out as novel urban structures in terms of their relationship with the sea. In this article, Eastern Mediterranean port-cities' urban life that has taken shape with international commerce and thus with the association of different cultures, and their distinctive urban space will be explored within the context of the dynamics that produce and differentiate them. In this way, we will search for an answer as to what makes the cities in question a port-city. What kind of differences and/ or similarities do the Eastern Mediterranean port-cities bear despite the fact that similar conditions and processes have influenced their spring and development? This question will be discussed through three Eastern Mediterranean port-cities, namely, Patras, Volos, and Mersin. It is aimed that this discussion would provide a means to interrogate the existence of an "Eastern Mediterranean port-city" character on the basis of the process of spatial structure and configuration.

Keywords: Eastern Mediterranean port-city, urban identity, Patras, Volos, Mersin

* Bu makale Dokuz Eylül Üniversitesi, Fen Bilimleri Enstitüsü, Sehir ve Bölge Planlama Bölümü'nde, 2016 yılında tamamlanmış “On Dokuzuncu Yüzyıldan Yirminci Yüzyıla Doğu Akdeniz Liman Kentlerinde Mekanın Dönüşümü: Volos, Patras ve Mersin” başlıklı doktora tezinden üretilmiştir. Çalışma kapsamında, gerek Yunanistan'da yürütülen arşiv araştırması için ve gerekse görüş ve önerileri ile katkı sağlayan, ayrıca kendi kişisel arşivinden yararlanmamıza izin veren, Aristotle University of Thessaloniki'den Prof. Dr. Vilma Hastaoglou-Martinidis'e, tez süresi boyunca değerli katkıları nedeniyle Prof. Dr. Filiz Yenişehirlioğlu'na ve Prof. Dr. İpek Özbek Sönmez'e teşekkür ederiz.

** Mersin Üniversitesi, Akdeniz Kent Araştırmaları Merkezi

*** Dokuz Eylül Üniversitesi, Şehir ve Bölge Planlama Bölümü 


\section{Giriş}

Liman kentleri, 19. yüzyılda, sömürgecilik ve kapitalizmle karşı karşıya gelen toplumların geçirdiği dönüşümün anlaşılması için bir laboratuvar olarak araştırmacıların daima ilgisini çekmiştir. ${ }^{1}$ Ancak pek çok araştırmada, liman kentinin kendisinden çok, çevreleşme süreçleri odakta yer almış, Doğu Akdeniz limanları, yalnızca meta değişiminin ve kapitalist karşılaşmaların kavşakları olarak değerlendirilmiştir. ${ }^{2}$ Dolayısıyla bu kentler, dönemin kapitalist ilişkileri, sömürgecilik tarihi ve modernleşme açısından taşıdığı ilgi çekici yönleri ile edilgen ve çoğunlukla "olayın cereyan ettiği yer" olarak değerlendirilmiştir.

Oysa, 19. yüzyıldan 20. yüzyıl başına kadarki süreç, yalnızca yukarıdan aşağıya ya da bir yönden diğerine ilerleyen bir süreç değildir. Doğu Akdeniz'i birbirine bağlantılı bazı ticari, siyasi ve kültürel değişimler bölgesi olarak görmek, 19. yüzyılda dönemin güç ilişkilerini biçimlendiren sürece ilişkin önemli ipuçları sunar. Ancak bu değişimlerin arkasında bir takım yerel koşul ve dinamikler vardır. ${ }^{3}$ Dolayısıyla, 19. yüzyılda Akdeniz'in doğusunda yaşanan köklü değişimde, küreselleşmeye başlayan ekonomik ilişkiler kadar, yerelin kendine özgü koşullarının da etkili olduğu ve süreci karşılıklı bir etkileşimin şekillendirdiği gözden kaçırılmamalıdır.

Dolayısıyla bu çalışmada, yerel-evrensel/merkez-çevre/parça-bütün arasındaki diyalektik ilişkiler uyarınca, üç liman kentinden yola çıkılarak, Akdeniz'in doğusundaki liman kentlerinin mekânsal yapısı ve biçimlenişine yönelik bir kavramsal çerçeve oluşturulacak; her biri Doğu Akdeniz liman kentleri ağının birer parçası olan Patras, Volos ve Mersin kentlerini ele alan bir inceleme ile her bir kent, kendi yerel bağlamı içinde değerlendirilecek; aynı zamanda, yerel koşulların yarattığı özgünlükler ile üst ölçekteki bütünün parçaları olmalarından kaynaklanan benzerlikler karşılaştırmalı olarak tartışılacaktır. ${ }^{4}$ Çalışmanın temel sorusu da bu çerçevede belirginleşmektedir. Söz konusu diyalektik ilişki doğrultusunda ortaya çıkan ya da gelişen Doğu Akdeniz liman kentleri için, özellikle mekânsal yapı ve biçimleri (ve elbette kentsel mekânın geçirdiği değişimler) doğrultusunda kavramsal bir çerçeve çizilebilir mi? Söz konusu kentleri kendine özgü kılan, onları "Doğu Akdeniz liman kenti” olarak tanımlayabileceğimiz bir "ortaklıklar kümesi" var mıdır ya da yere özgü koşulların ürettiği farklilıklar nelerdir?

Bu soruya, 19. yüzyıldan 20. yüzyıl başına kadarki süreçte, Patras, Volos ve Mersin'in geçirdiği değişimler üzerinden yanıt aranacaktır. Bunun için, iktisadi ve sosyal yapıdaki değişimlerle birlikte, bu kentlere kimlik ve karakter

1 Çağlar Keyder, "Belle Epoque ve Liman Kentleri”, Osmanlılardan Günümüze Doğu Akdeniz Kentleri içinde, der. Biray Kolluoğlu ve Meltem Toksöz (İstanbul: Türkiye İş Bankası Kültür Yayınları, 2015), 17-28.

2 Biray Kolluoğlu ve Meltem Toksöz, “Doğu Akdeniz'in Haritalandırması: Ticaret Kentleri Kartografyasına Doğru”, Osmanlılardan Günümüze Doğu Akdeniz Kentleri içinde, der. Biray Kolluoğlu ve Meltem Toksöz (İstanbul: Türkiye İş Bankası Kültür Yayınları, 2015), 1-16.

3 İsa Blumi, "Doğu Akdeniz'e Yeni Tarihsel Ölçekler Eklemek: Yasadışı Ticaret ve Arnavut", Osmanlılardan Günümüze Doğu Akdeniz Kentleri içinde, der. Biray Kolluoğlu ve Meltem Toksöz (İstanbul: Türkiye İş Bankası Kültür Yayınları, 2015), 139-167.

4 Kolluoğlu ve Toksöz, tekil örnekler üzerinde yoğunlaşan çalışmaların, liman kentlerine ilişkin literatüre katkısını vurgulamakta ancak, bu çalışmaların karşılaştırmayı güçleştiren bir yanı olduğunu ve tekil örneklerin ağırlıklı olarak, söz konusu kentleri Osmanlı İmparatorluk merkezi ile ilişkileri üzerinden ele aldıklarını öne sürmektedir. Bu durum, söz konusu kentleri edilgenleştirmekte ve özgünlüklerini silikleştirmektedir. Öte yandan, dünya sistemi perspektifini esas alan çalışmalarda dünya ekonomisinin ağırlık kazandığı ve yerelin renklerinin ise yeterince yer bulamadığı görülmektedir. Bkz. Kolluoğlu ve Toksöz, "Doğu Akdeniz'in Haritalandırması". 
kazandıran ortaklık, benzerlik ya da farklılık gösteren mekânsal yapı incelenecektir. Söz konusu liman kentlerine kimlik ve karakter kazandıran ortaklık ve benzerlikler, "geçmişten gelen ve değişmez bir olgu" biçiminde verili olarak ele alınmayacak, tam aksine Doğu Akdeniz liman kentlerinin kimlik ve karakterinin içsel dinamikler ile dışsal süreçlerin karşılıklı etkileşimi içinde sürekli dönüşerek yeniden biçimlendiği düşüncesinden hareketle, bu değişimin de benzerlik ve farklılıkları ortaya konmaya çalışılacaktır.

Doğu Akdeniz liman kenti ağırlıklı olarak, dönemin değişen ekonomik yapı ve örgütlenmesini anlamayı ve açılamayı sağlayacak önemli bir düzlem olarak ele alındığından, bu alandaki çalışmalar da ağırlıklı olarak, İstanbul, İzmir, İskenderiye, Beyrut, Selanik, Pire gibi, söz konusu değişimin birincil düğüm noktaları olan kentler üzerinde yoğunlaşmış, daha alt sırada yer alan kentlerse, çoğunlukla, üst sırada yer alan liman kentleri ile ilişkileri ölçüsünde ele alınmışlardır.

Oysa, Doğu Akdeniz liman kentleri hiyerarşisinde daha alt kademedeki liman kentleri, özellikle demiryolu yatırımlarıyla, iç kesimlerle güçlü bağlantılar kurmuş ve kimi zaman ana limanları besleyen bir antrepo, kimi zaman da Batı'nın siyasi ve ekonomik nüfuzunun en ücra köşeye kadar ulaşmasında birer kılcal damar olarak önemli bir işlev görmüştür. ${ }^{5}$ Çalışma kapsamında incelenen kentler, Patras, Volos ve Mersin, bu çerçevede belirlenmiştir. Söz konusu kentlerin seçimindeki birinci ölçüt, kentin, Doğu Akdeniz liman kentleri ağının hiyerarşik yapısındaki yeri olurken, bir başka ölçüt coğrafi konum olmuştur. Her üç kent de Doğu Akdeniz coğrafyasında halen varlıklarını sürdürmektedir. Patras yönünü Avrupa'ya çevirmiş en batı noktada; Volos, doğu ve batı arasında ve Mersin, söz konusu kentler arasında en doğu noktadaki limanlardır. Dolayısıyla, 19. yüzyılda, hiyerarşik kademelenmede eş konumdaki bu üç Doğu Akdeniz liman kenti, ortaya çıkacak benzerlik ya da farklılıklar ile yere özgü koşullar arasındaki ilişkinin anlaşılması ve bunun söz konusu kentlerin kimlik ve karakteri üzerindeki etkisinin tartışılması için önemli olanaklar sunacaktır.

Bu kentler, günümüzde iki ayrı ulus-devlet sınırları içindedir. Dolayısıyla, yalnızca ulus-devletleşme süreçleri ve uygulamaya çalıştıkları modernite projeleriyle değil, ortak kültürel geçmiş̧leriyle de önemli benzerlikler gösterdiğ $i$ düşünülen, Yunanistan ve Türkiye gibi iki ülke sınırları içinde yer almaları, yapılacak karşılaştırma için verimli bir zemin sağlayacaktır.

Çalışma kapsamında Patras, Volos ve Mersin kentleri için, yerel arşivlerden, ulusal ve uluslararası arşivlere uzanan bir araştırma yapılmıştır. Başbakanlık Osmanlı ve Cumhuriyet Arşivi, Milli Kütüphane gibi ulusal arşivler, SALT Araştırma gibi özel arşivlerin dışında, British Library, Nantes Diplomatik Arşivi, Library of University of Thessaly, DIKI (Municipal Center for Historical Research and Documentation of Volos), Library of Municipality of Patras, Library of University of Patras (Library of Faculty of Architecture), Gennadius Library, ELIA (The Hellenic Literary and Historical Archive), Aristotle University of Thessaloniki Library, Central Municipality Library of Thessaloniki'de araştırmalar yapılmıştır.

Mersin için elde edilen bilgiler dışında, Patras ve Volos'a inceleme ve araştırma gezisi gerçekleştirilmiş, kurumsal arşiv ve kütüphanelerden, yazılı belgelerin yanı sıra, harita, plan, kartpostal ve fotoğraf gibi mekânsal gelişime ilişkin belgelere ulaşılmış, kentin güncel fotoğraf arşivi oluşturulmuş, ayrıca kişisel arşiv ve koleksiyonlar, kartpostal ve fotoğraf gibi görsel malzemeler 
değerlendirilmiştir. Birincil kaynaklar olan Şark Ticaret Yıllıkları (Annuaire Oriental) ve yine her üç kent için de farklı arşivlerden ulaşılan İngiliz Konsolosluk Raporları kullanılmıştır.

Söz konusu araştırmalar sonucunda, Doğu Akdeniz liman kentlerine ilişkin çoğunlukla iktisadi ve tarihi bir perspektif üzerinden oluşturulan kuramsal çerçeve dışında, sosyo-mekânsal yaklaşıma dayalı yeni ve özgün bir ele alış geliştirilmeye çalışılmıştır. Çalışmada, söz konusu kentlerin kendine özgü mekânsal pratikleri ele alınacak ve değerlendirilecektir. Bunun için öncelikle, kentlerin içinde yer aldıkları bağlam ortaya konulacaktır.

\section{Akdeniz-Doğu Akdeniz ve 19. Yüzyılda Doğu Akdeniz Liman Kentleri} Avrupa ve Afrika kıtaları arasında deniz eksenli bir coğrafya olarak Akdeniz, ortak bir deniz etrafında yer alan, kıyılardan dağlara kadar geniş bir alana karşılık gelir. ${ }^{6}$ Doğu Akdeniz ise özellikle kapitalist ekonomi ve ilişkilerin birincil mekânları olarak liman kentlerinde yaşanan köklü değişim temelinde kavramsallaştırılabilecek, Yunanistan'ın batı kıyılarından, doğuda Suriye, Lübnan ve İsrail kıyılarına kadar devam eden bir coğrafya olarak tanımlanabilir. "Doğu Akdeniz", özellikle 19. yüzyllla birlikte, yerel ile küreselin, ulusal ile uluslararasının, içsel dinamikler ile dışsal süreçlerin karşılıklı etkileşimi sonucunda gerçekleşen değişimin belirgin bir biçimde incelenebileceği özel bir coğrafya olarak karşımıza çıkar.

Kapitalizmin yayılmacı eğilimi doğrultusunda şekillenen üretim biçim ve ilişkileri ile ticarette, yaşam kültüründe ve kentsel mekânda meydana gelen değişimler, 19. yüzyılda Akdeniz'in doğusunda yapısal bir dönüşüme yol açmıştır. Bu dönüşümün somut etkileri, başta İngiltere ve Fransa olmak üzere sanayileşmiş merkez ülkelerin, Akdeniz'deki rekabeti ve ulaşım/iletişim olanaklarındaki teknolojik yeniliklerle gelişen deniz ticaretiyle, Akdeniz'in doğusundaki liman kentlerinde kendini göstermiştir. Kapitalizmin sınır ötesi mekânsal örgütlenme gereksinimiyle mal aktarımını hızlandırmak ve kârlılığ1 artırmaya yönelik olarak başlayan demiryolu, karayolu, iskele, rıhtım, liman gibi ulaşım altyapısına yönelik yatırımlar, kentlerin merkez ile bütünleşmesini sağlarken aynı zamanda, Doğu Akdeniz liman kentlerinde benzeşen mekânsal yapı ve pratiklerin oluşmasına da zemin hazırlamıştır. ${ }^{7}$ Bu da söz konusu kentlerde gereksinim duyulan yeni kentsel hizmetlerin, geleneksel Osmanlı kent yapı ve kurumları ile karşılanmasını güçleştirmiştir. ${ }^{8}$ Dolayısıyla Osmanlı, dönemin Avrupa kentlerini model alarak, kentsel mekânın yeniden düzenlenmesi için yabancı uzmanların görüşlerine başvurmuştur. ${ }^{9}$ Yapılan düzenlemelerle, geçmişte merkezi otoritenin kontrolünde şekillenen kentsel mekân ve mimarinin, yerel koşullara uyumlu özgün uygulamalarla yeniden şekillendirilmesi

6 Eyüp Özveren, “Geçmişten Geleceğe Akdeniz Dünyası”, Akdeniz Uygarlıkları Sanatı içinde, der. Filiz Çalışlar Yenişehirlioğlu (Eskişehir: Anadolu Üniversitesi Yayınları, 2012), 2-23.

7 Kurmuş, Emperyalizmin Türkiye'ye Girişi; Vilma Hastaoglou-Martinidis, “Doğu Akdeniz Kentlerinde Liman İnşaatının Kartografyası: 19. Yüzyıl Sonunda Teknik ve Kentsel Modernleşme", Osmanlılardan Günümüze Doğu Akdeniz Kentleri içinde, der. Biray Kolluoğlu ve Meltem Toksöz (İstanbul: Türkiye İş Bankası Kültür Yayınları, 2015), 95-120.

8 İlhan Tekeli, “Türkiye'de Cumhuriyet Döneminde Kentsel Gelişme ve Kent Planlaması”, 75 Yılda Değişen Kent ve Mimarlık içinde, der. Yıldız Sey (İstanbul: Tarih Vakfı Yurt Yayınları, 1998), 1-24; İlhan Tekeli, “19. Yüzyılda İstanbul Metropol Alanının Dönüşümü”, Modernleşme Sürecinde Osmanlı Kentleri içinde, der. Paul Dumont ve François Georgeon (İstanbul: Tarih Vakfı Yayınları, 1999), 19-30.

9 Zeynep Çelik, 19. Yüzyılda Osmanlı Başkenti Değişen İstanbul, çev. Selim Deringil. (İstanbul: Tarih Vakfı Yurt Yayınları, 1998). 
hedeflenmiş, bu da kentlere yeni bir doku ve fiziksel görünüm kazandırmıştır. ${ }^{10}$ Başta İstanbul olmak üzere, tüm bu değişimler ise "Batılı anlamda kent ve kentli yaşam biçimi"ne, Batı ile ticaret temelinde kurdukları ilişkiler nedeniyle, hizla uyum sağlayan yerler olarak liman kentlerinde kendini somut olarak göstermiştir. Osmanlı idaresindeki Doğu Akdeniz liman kentlerinde değişim mekânsal olarak, yeni yönetsel yapıların inşası, liman, rıhtım, demiryolu, karayolu gibi altyapı yatırımları ile kendini gösterirken, sosyo-ekonomik alanda ise yeni ticari ilişkiler ve demografik değişimlerle ortaya çıkmıştır. ${ }^{11}$ Dolayısıyla Doğu Akdeniz'de, Osmanlı egemenliğindeki liman kentlerinde kentsel mekân, bir yandan Osmanlı modernleşmesinin yeni düzenlemeleri etkisinde gelişirken bir yandan da kapitalist üretim ilişkileri doğrultusunda, yerelin değişen gereksinimleri ve talepleri ile şekillenmiştir.

Ancak söz konusu değişimlerin yanı sıra, farklı nüfus gruplarının yaşadığ1 geniş coğrafyasıyla imparatorluk, bu dönemde dünyada yaşanan toplumsal gelişmelerden de etkilenmiştir. 19. yüzyılın sonlarına doğru ulusçu akımlar, özellikle Balkanlar'da yaşayan farklı nüfus gruplarını etkilemiş ve ulus-devletlerin kurulmasına giden süreci başlatmıştır. Bu süreçte söz konusu kentler, 20. yüzyılın başından itibaren kurulan ulus-devletler ve bu devletlerin uygulamaya koyduğu yeni bir modernleşme süreci ile karşı karşıya kalmışlardır.

19. yüzyılda, sermaye birikimi sağlamış olan ve sınıfsal ayrımları ve kültürel çeşitliliği ile bu kentler, 20. yüzyılın ilk yarısından itibaren ulus-devlet modelinin, ulusal değerlere ve milli kültüre vurgu yapan ideolojisi ile karşılaşmıştır. Bu karşılaşma, bir yandan modernleşme projesi için uygulama kolaylığ1 sağlarken öte yandan, liman kenti kimliğinin sosyal ve mekânsal çeşitliliği ve aralarındaki ilişkisel bütünlüğü değiştirmiştir.

Kuşkusuz Yunanistan ve Türkiye'nin ulus-devlet olma süreçleri birbirinden farklılıklar içermektedir. Ancak gerek Yunanistan ve gerekse Türkiye'de uygulanması hedeflenen modernite projesi, yeni bir ulus yaratma ideali ile nüfusun ve kentsel mekânın homojenleştirilmesini esas almıştır. Bu yaklaşım, kentlerin geçmişten gelen ve belli ilişkisellikler çerçevesinde şekillenen karakterini değiştirmiştir. Bu değişim kimlik ve karakterini, özellikle denizle kurdukları ilişkiye, sahip oldukları sosyal ve mekânsal çeşitliliğe borçlu olan liman kentlerinde belirgin biçimde yaşanmıştır (Şekil 1).

Bu noktada beliren soru, bu süreçte, söz konusu kentlerin nasıl bir mekânsal yapı ile gelişip ne tür değişimler geçirdiğidir. Ancak öncelikle, çalışmada, kent kimliği ve karakteri kavramlarının nasıl ele alındığı üzerinde durulacaktır.

10 Filiz Yenişehirlioğlu, "Urban Texture and Architectural Styles After the Tanzimat", Economy and Society on Both Shores of the Aegean içinde, der. Lorans Tanatar Baruh, Vangelis Kechriotis (Atina: Alpha Bank, 2010), 487-526.

11 Çağlar Keyder, Eyüp Özveren, Donald Quatert, “Osmanlı İmparatorluğu'nda Liman Kentleri: Bazı Kuramsal ve Tarihsel Perspektifler", Doğu Akdeniz'de Liman Kentleri (18001914) içinde, der. Çağlar Keyder, Eyüp Özveren, Donald Ouataert (İstanbul: Tarih Vakfı Yurt Yayınları, 1994), 121-155; Reşat Kasaba, Dünya Imparatorluk ve Toplum: Osmanlı Yazıları, çev. M. Banu Büyükkal. (İstanbul: Kitap Yayınevi, 2005). 


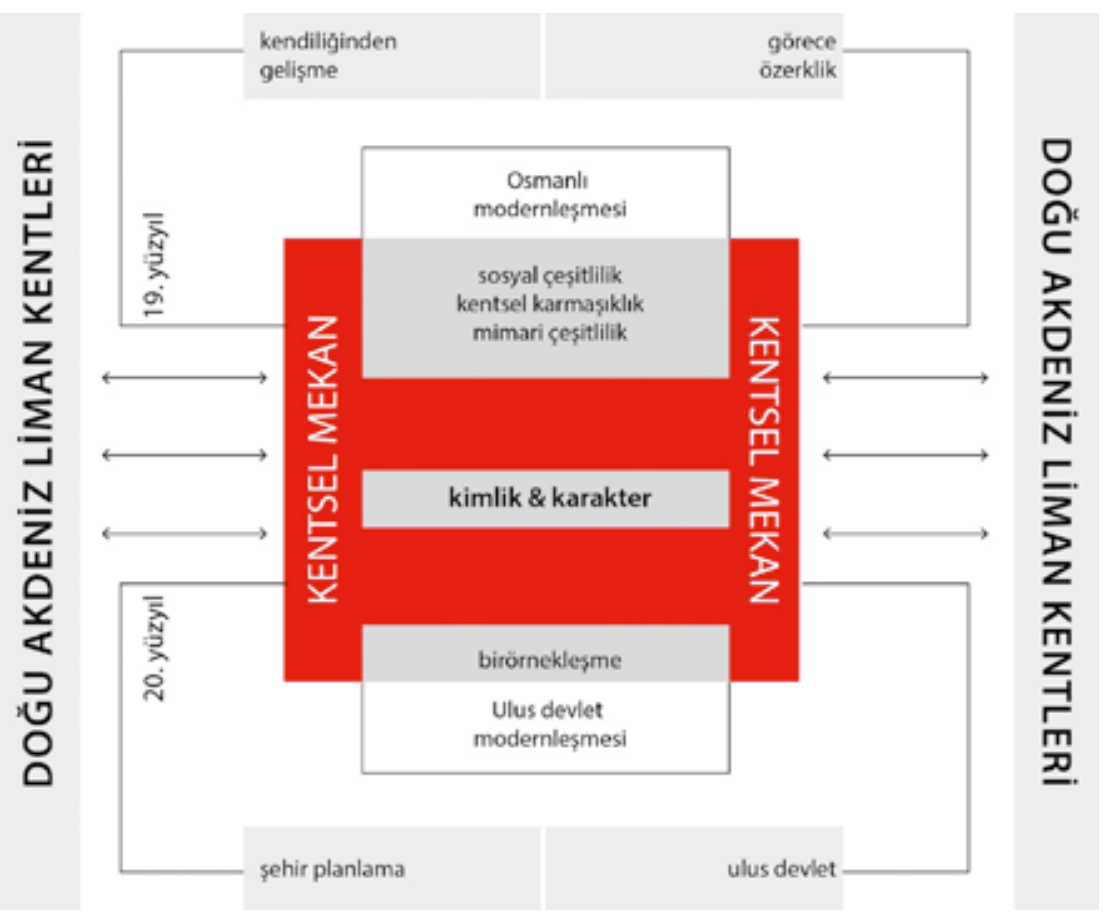

Şekil 1. İki farklı modernleşme sürecinde, liman kentinin geçirdiği değişim.

\section{Kent Kimliği ve Karakteri}

Kentler, onları birbirinden ayırt eden çeşitli nitelikleri doğrultusunda, farklı biçimlerde adlandırılmış ve tanımlanmışlardır. Söz konusu tanımlamalara bakıldığında, doğal çevre koşulları ve sosyal çevreden temel alan kültürel yapı ve yapılı çevrenin, kentleri tanımlama ve sınıflandırmada belirleyici olduğu görülür. ${ }^{12}$ Yapılı çevre, onu üreten toplumun izlerini taşır ve bu da onu, coğrafya, iklim, topoğrafya gibi verili koşullarla birlikte diğerlerinden farklılaştırır. Dolayısıyla bu çalışmada, bütün bu bileşenler arasında diyalektik bir ilişki olduğu ve birlikte kentin kimliğini oluşturduğu görüşünden hareketle, kent kimliği kavramı ile kentleri diğerlerinden farklılaştıran, doğal, sosyal ve yapılı çevre arasındaki ilişki ve etkileşimler işaret edilmektedir.

Buradan hareketle çalışmada, coğrafi, sosyal ve ekonomik yapıyla ilişki içinde olan kentsel mekâna bağlı kimlik üzerinde durulmaktadır. Dolayısıyla, coğrafi, sosyal ve ekonomik yapıya ilişkin değişimler göz ardı edilmeden, temel olarak mekânsal yapı üzerinden bir kimlik tanımı esas alınmaktadır. Çünkü, kentin kimliğinin oluşumunda, biçim (form), konum (bağlam), kullanım türü (işlev/fonksiyon) ve anlamları ile bir bütün oluşturan mekânsal yapı önemli rol oynar. ${ }^{13}$

Sahip olduğu ticari etkinlik ve deniz kıyısındaki konumuyla "liman kenti”

12 Tülin Selvi Ünlü, “On Dokuzuncu Yüzyıldan Yirminci Yüzyıla Doğu Akdeniz Liman Kentlerinde Mekanın Dönüşümü: Volos, Patras ve Mersin” (Doktora Tezi, Dokuz Eylül Üniversitesi, 2016), 83-93.

13 Hande Suher, Mehmet Ocakçı, Hatice Karabay Ayataç, Özhan Ertekin, "An Indicator of Sustainable Development: Urban Identity", A/Z ITU Journal of the Faculty of Architecture 1, no. 2 (2004): 27. 
olarak adlandırılan çok sayıda kent vardır. Ancak, "liman kenti" olarak ortak bir kimlik sınıflandırması içinde yer alan bu kentlerin her biri birbirinden farklı bazı fiziksel özellikler gösterebilir. Dolayısıyla kentlerin, kendine özgü mekânsal yapıları ve fiziksel özellikleri ile farklı bir "karakter"e sahip oldukları görülür. Örneğin, İskenderiye de Cenova da birer liman kenti olmasına karşın, birbirlerinden tamamen farklı fiziksel özelliklere sahiptirler.

Dolayısıyla, yalnızca o "yer"e özgü mekânsal bileşenler, kentin karakterine işaret eder ve bu kimliğin bir parçasıdır. Kent kimliği, mekânın, onu üreten, üretim biçim ve ilişkileriyle bir bütün olarak ele alındığında beliren özgünlüklerine karşılık gelirken; şekil, doku, renk gibi somut fiziksel özellikler ise bir bütün olarak karakteri oluşturur. ${ }^{14}$ Peki Doğu Akdeniz liman kenti kimliği ve onun bir parçası olan karakteri nasıl tanımlanabilir?

Doğu Akdeniz liman kentine özgü nitelikleri ortaya koymaya yönelik çeşitli çalışmalar yapılmıştır. Driessen, kozmopolitanizm kavramı üzerinden, Akdeniz liman kentinin, iç kesimlerdeki kentlerden farklılıklarını tartışmış ve benzerlik ya da ortaklıklara ilişkin kesin ve genelleyici yargılardan kaçınmak gerektiğini vurgulamıştır. ${ }^{15}$ Pace de benzer biçimde Akdeniz kentinin, Akdeniz insanının kurduğu kültürel yapıya dayalı, ortak sosyal deneyimin ürettiği bir kimlik taşıdığını, ancak bu genel tanımlamanın içinde, tek bir Akdeniz kenti modelinden söz etmenin güç olduğunu belirtmiştir. ${ }^{16}$ Leontidou'ya göre, Akdeniz kentleri kendiliğinden gelişen bir doku ile toplumsal olarak üretilmiş, Batı kentindeki sınıfsal ayrışma ve işlevsel bölgelemeye dayalı yapının aksine Akdeniz kentlerinde, sosyal gruplar ve sinıflar ile farklı kullanımların bir arada olduğu bir kentsel yapı gelişmiştir. ${ }^{17}$ Fuhrmann ve Kechriotis ise aralarındaki değişmez rekabet ve farklılıklara rağmen bu kentlerde ortak kentleşme deneyimlerinin yaşandığını ve kendi kendine yeten bir kentliliğin olduğunu öne sürmüştür. ${ }^{18}$

Kolluoğlu ve Toksöz, liman işlevine dayalı olarak, depo ve antrepolar, gümrük binaları, gemicilik şirketleri, acenteler, sigorta şirketleri gibi ticari kullanımların kentsel mekânda kendini gösterdiği bu kentlerin, 19. yüzyılda, kendine özgü sosyal ilişkilerin ürettiği mekânsal karakteristikleriyle dikkat çektiklerine vurgu yapmıştır. Bu kentler, ulaşımda raylı sistemin kullanıldığı, çeşitli dini yapıların bir arada bulunduğu ancak kentsel mekânda bunların baskın bir öğe olmadığı, sosyal ilişkilerin canlılığını somut olarak ortaya koyan sinema, kulüp, dans salonları, kıraathaneler, bahçeler, gezinti yolları gibi kamusal kullanımların yer aldığı ve tek bir mimari akım ya da dilin egemen olmadığı bir mekânsal yapıya sahiptir. ${ }^{19}$

Katsiardi-Hering, farklı inançlara ait dini yapılar, kıyı boyunca devam eden gezinti yolları, sırtlardaki kale ve eski kentten sahile inen dar sokaklar, deniz

14 Christian Norberg-Schulz, "The Phenomenon of Place", Designing Cities: Critical Readings in Urban Design içinde, der. Alexander R. Cuthbert (Malden, MA: Blackwell, 2006), 116.

15 H. Driessen, "Mediterranean Port Cities: Cosmopolitanism Reconsidered", History and Anthropology 14, no. 1 (2005): 130.

16 Giuseppe Pace, "Ways of Thinking and Looking at the Mediterranean City", Munich Personal RePEc Archive (2002): 11, http://mpra.ub.uni-muenchen.de/10511.

17 Lila Leontidou, The Mediterranean City in Transition: Social Change and Urban Development (New York: Cambridge University Press, 2006), 7-11.

18 Malte Fuhrmann ve Vangelis Kechriotis, "The Late Ottoman Port-Cities and Their Inhabitants: Subjectivity, Urbanity, and Conflicting Orders", Mediterranean Historical Review 24, no. 2 (2009): 72.

19 Kolluoğlu ve Toksöz, "Doğu Akdeniz'in Haritalandırması", 7. 
kıyısındaki geniş alanlar, düzenli, modern tarzdaki yeni yapılar gibi pek çok fiziksel bileşenin, bu kentlere ortak bir kimlik kazandırdığını söylemiştir. ${ }^{20}$ Katsiardi-Hering, kıyı şeridi, farklı toplulukların bir arada yaşadığına işaret eden farklı dini yapılar ve mahallelerin bu ortak kimliğin en belirgin bileşenleri olduğunu dile getirmiştir. ${ }^{21}$

Pallini, 1850'lerden itibaren buharlı gemi teknolojisiyle ulaşımda yaşanan değişimle Doğu Akdeniz'de "ticaretin coğrafyası"nın yeniden tanımlandığını ve Doğu Akdeniz liman kentlerinin kamusal binalarının, bu dönemin modernizm anlayışını ve kültürel kimliğin farklı yorumlanış biçimlerini yansıttığını belirtmiştir. ${ }^{22}$ Pallini'nin bu yorumu, söz konusu kentlerin, liman kenti kimliği ile mekânsal yapıları arasındaki güçlü ilişkiyi ortaya koyması açısından önemlidir. Tıpkı günümüz metropolleri gibi, ticari ağların odak noktasında yer alan bu kentler, çeşitlilik gösteren bir demografik yapı ile gelişmişler, söz konusu demografik çeşitlilik ve bu kentlerin gelişmelerinde temel belirleyicilerden biri olarak ticaret, mekânsal yapının biçimlenişinde etkili olmuştur. ${ }^{23}$

O halde, "liman kenti", hatta "Doğu Akdeniz liman kenti" olarak adlandırılan kentlerin, onların bu genel sınıflandırma içinde yer almalarında etkili olan ekonomik, coğrafi ve sosyal özelliklerinin neler olduğunu tartışmak, onlara karakter kazandıran mekânsal yapı ve bileşenlerine bakmak yararlı olacaktır.

\section{Yüzyıldan 20. Yüzyıla Doğu Akdeniz Liman Kentlerinde Kentsel Mekân ve Değişimi}

Doğu Akdeniz liman kenti kimlik ve karakterini ürettiği öngörülen bu sürece ilişkin kavramsal bir çerçeve geliştirmek için, seçilen üç liman kentinin geçirdikleri değişime bakılacaktır. Kentsel mekânın biçimlenişindeki süreç ve aktörler dikkate alındığında, söz konusu değişimi temel olarak üç aşamada ele almak olanaklidir.

\section{İk Aşama}

Patras ve Volos, 19. yüzyıl öncesinde, birer Osmanlı kale yerleşimi iken Mersin bu dönemde henüz birkaç iskeleden ibarettir. Ancak her üç kentin liman işleviyle gelişmelerinde, içinde bulundukları coğrafyadaki tarımsal üretim ve bu ürünlerin merkez ülkelere aktarımı etkili olmuştur. Mora Yarımadası́nda Achia bölgesindeki üzüm üretimi Patras'ın, Yunanistan'in Teselya Ovası'ndaki tahıl üretimi Volos'un, Çukurova'daki pamuk üretimi Mersin'in Doğu Akdeniz'de birer aktarım noktası olarak gelişmesine ilk ivmeyi vermiştir.

Her üç kent de Fransa ve İngiltere başta olmak üzere, sanayileşmiş ülkelerin tarımsal ürünlere yönelik talepleri için bir kaynak olurken aynı zamanda, bu ülkelerin mamul malları için birer pazar olmuştur. Patras ve Volos'un Osmanlı döneminde birer kale yerleşiminden liman kentine evrildiği, Mersin'in ise yepyeni bir kent olarak ortaya çıktı̆̆ı bu dönem, Balkan ülkeleri ve Osmanlı'da, serbest ticaret antlaşmaları ile başlayıp ilerleyen yeni ekonomik ilişkilerin kendini gösterdiği dönemdir. Dolayısıyla her üç kentin de 1800 'lü yıllardan itibaren, birer liman olarak gelişmelerinde, iktisadi değişimler ve coğrafi bağlam etkili olmuştur (Şekil 2).

20 Olga Katsiardi-Hering, "City-ports in the Eastern and Central Mediterranean from the Midsixteenth to the Nineteenth Century: Urban and Social Aspects", Mediterranean Historical Review 26, no. 2 (2011): 153.

21 Katsiardi-Hering, "City-ports in the Eastern and Central Mediterranean", 152-153.

22 Cristina Pallini, “Doğu Akdeniz'de Coğrafi Tiyatrolar, Liman Peyzajları ve Mimari: Selanik, İskenderiye, İzmir", Osmanlılardan Günümüze Doğu Akdeniz Kentleri içinde, der. Biray Kolluoğlu ve Meltem Toksöz (İstanbul: Türkiye İş Bankası Kültür Yayınları, 2015), 61.

23 Kolluoğlu ve Toksöz, "Doğu Akdeniz'in Haritalandırması”, 4. 


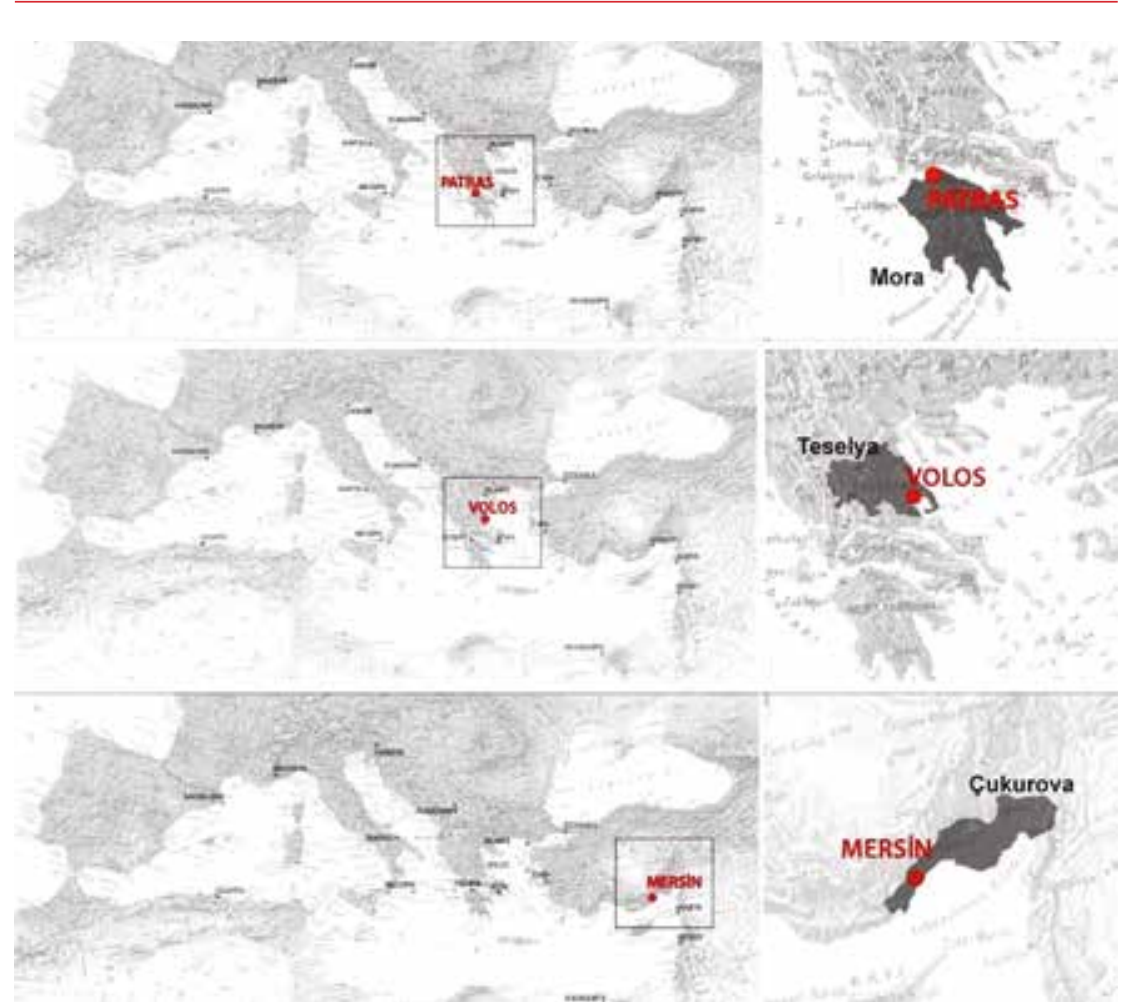

Şekil 2. Patras, Volos ve Mersin'in Doğu Akdeniz'deki konumu ve art alanları.

Her üç kentin ve içinde yer aldıkları bölgenin iktisadi yapısındaki değişimlerin, mekândaki belki de ilk somut yansıması demiryollarıyla olmuştur. ${ }^{24} 1881$ yılında imzalanan anlaşma ile inşa edilen Volos-Larisa hattı, 1884-1887 arasında inşa edilen ve Patras'ı Yunan anakarasına bağlayan demiryolu ve 1886 yılında açılan Mersin-Adana demiryolu yabancı yatırımcılar tarafından hayata geçirilmiştir. ${ }^{25}$ Demiryolları, Patras, Volos ve Mersin'de, limandaki ana iskeleyle bağlantılı biçimde kente girmiş, yalnızca ürün taşımacılığında değil, kentiçi ulaşımda da kullanılmıştır. Böylelikle demiryolu, ticari etkinliği arttırmakla kalmamış, her üç kentte de mekânsal yapının temel bileşenlerinden biri olmuştur.

Ancak değişen iktisadi yapının bu kentlerdeki tek somut yansıması demiryolları değildir. Her üç kentte de henüz büyük ve bölgesel ölçekli altyapı yatırımları söz konusu olmasa da yerel tüccarlar ve yabancı girişimcilerin talepleriyle, küçük ölçekli iskele, mendirek, rıhtım gibi çeşitli düzenlemeler yapılmaya

24 Bu dönemde demiryolu, yatırımın yapıldı̆̆ ülkenin değişik bölgelerini birbirine bağlamaktan çok, yeraltı kaynakları ve tarımsal açıdan zengin bölgeleri, merkez ülkelerin sanayi bölgelerine bağlamaya yönelik yatırımlar olarak kendini göstermiştir. Bkz. Kurmuş, Emperyalizmin Türkiye'ye Girişi.

25 James Waite, "The Railways of Volos", The International Steam Pages, http://www. internationalsteam.co.uk/trains/greece02.htm, erişim tarihi 14 Mart 2016; Municipality of Patras, Haritalar ve Hatıralar 1813-1943 (Patras: Patras Belediyesi, 2014), 176 (Yunanca); Elena Frangakis-Syrett, "Patras", Doğu Akdeniz'de Liman Kentleri (1800-1914) içinde, derleyenler Çağlar Keyder, Eyüp Özveren, Donald Ouataert (İstanbul: Tarih Vakfı Yurt Yayınları, 1994), 32; Emine Dingeç, “19. Yüzyılın İkinci Yarısında ve 20. Yüzyılın Başında Mersin'in Ekonomik Yapısı" (Yüksek Lisans Tezi, Anadolu Üniversitesi, 1998), 76-77. 
başlamış, liman, liman tesisleri inşası ve modernleştirilmesi, antrepolar ve gümrük binalarının yapılması gibi pek çok uygulama kendini göstermiştir. ${ }^{26}$

Büyük ölçekli altyapı yatırımları Patras'ta, 1870'li yıllardan itibaren kendini göstermeye başlamış, Fransız şirketleri tarafından Patras Limanı ve tesisleri inşa edilmiştir. ${ }^{27}$ Ayrıca 1872 yılında, ana iskelenin batısında bir dalgakıran yapılması planlanmış, ${ }^{28} 1886$ yılında körfezin deniz araçları için daha korunaklı ve güvenli hale getirilmesi için kıyıda çeşitli düzenlemeler yapılmaya başlanmıştır. ${ }^{29}$ Benzer süreç Volos'ta da yaşanmıştır. Kent, doğal bir körfeze sahip olmasına karşın 1880'li yıllara kadar, limandaki altyapı eksiklikleri nedeniyle deniz ticaretinde çeşitli aksaklıklar söz konusu olmuştur. Kentin 1881 yılında Yunan Devleti'ne katılmasından sonra bir "Liman Komisyonu" kurulmuş ve liman inşasına yönelik çalışmalar, aşama aşama gerçekleştirilmiştir. Uygun derinliğin sağlanması için denizin dibi taranmış, rıhtım, mendirek inşa edilmiş ve ana iskele uzatılmıştır. ${ }^{30} 1889-1910$ yılları arasında devam eden liman inşaatıyla birlikte kent, ticaretin yanı sıra sanayi alanında da gelişmeye başlamıştır. ${ }^{31}$

Mersin'de ise 1850'li yıllardan itibaren, iskelelerin sayıları artmış, var olanların tamiri ve rıhtım inşası gibi taleplerle, yükleme ve boşaltma işlemlerini kolaylaştırmak ve artan ticaret hacmini karşılamak için 1899 yılında yeni bir liman ve rıhtım yapımına karar verilmiştir. 1904 yılında yapımı tamamlanan rıhtım sayesinde gemiler artık kıyıya yanaşabilmektedir. ${ }^{32}$

İnşa edilen iskele, rıhtım, liman, demiryolu gibi yeni ulaşım biçimleri ve bunların yarattığı ilişkilerin sonucu olarak, her üç kentte de bankalar, sigorta şirketleri, iş hanları gibi ticari faaliyete yönelik yapılar, konaklama ihtiyacını karşılamak üzere otel, iletişim sağlamaya yönelik postane, telgrafhane gibi kullanımlar kendini göstermiştir. Dönemin ticari verileri incelendiğinde ${ }^{33}$ her üç kentte de söz konusu faaliyetlerin çeşitliliği kadar, benzer ticari faaliyet türlerinin varlığı dikkat çekmektedir (Tablo 1).

Üç kentte de başta finans sektörü olmak üzere, uzmanlaşmış hizmetler düzenli olarak artmıştır. Finans sektöründe, bankacılık, bankerlik ve sigortacılık gibi ticari etkinlikler yer alırken, avukatlıktan ayakkabı tamirciliğine, denizcilik acentesinden cilt işine yönelik atölyelere, dişçiden gemi zarar tespit şirketlerine kadar oldukça farklı iş kolunda uzmanlaşmış tüccar, ticarethane ve şirket faaliyet göstermeye başlamıştır. Ayrıca, perakende ticaret yapan çok sayıda tüccarın da artan kent nüfusunun gereksinimlerini karşılamak üzere faaliyet gösterdiği izlenmektedir (Tablo 2).

26 Hastaoglou-Martinidis, “Doğu Akdeniz Kentlerinde Liman İnşaatının Kartografyası”.

27 Frangakis-Syrett, "Patras", 32.

28 N. Bakounakis, "19. Yüzyılda Patras'ın Sosyo-ekonomik Durumu", Antik Dönemden Günümüze Patras içinde, der. E. Sklavenitis, K. Staikos (Atina: Kotinos, 2005), 144 (Yunanca); A. Simeonidou, "Pire, Volos ve Patras Limanları: Finansal Gelişim" (Yüksek Lisans Tezi, Kavala Teknolojik Eğitim Enstitüsü, 2015), 54 (Yunanca).

29 House of Commons Parliamentary Papers, Report by Consul Thomas Wood, Trade of the Consular District of Patras, 1886, No: 78.

30 A. Dimoglou ve L. Mourtzoukos, Volos then \& now (Atina: Olkos, 2006), 147-148.

31 Vilma Hastaoglou-Martinidis, Volos: Portrait of the City from the 19th Century to Today (Volos: DIKI, 2007), 256 (Yunanca).

32 Tülin Selvi Ünlü, "19. Yüzyılda Mersin'in Kentsel Gelişimi” (Yüksek Lisans Tezi, Mersin Üniversitesi, 2007), 128-148.

33 Anlamlı sonuçlar elde edebilmek için, her üç kent için de dört, beş ya da altı yıllık periyodlarla, 1885-1930 yılları arasını kapsayan Şark Ticaret Yıllıkları esas alınmıştır. Konsolosluk raporlarında ise 1800-1900 yılları arasındaki dönem verileri üzerinden bir değerlendirme yapılmıştır. 
Ünlü - Göksu

\begin{tabular}{|c|c|c|}
\hline \multirow{3}{*}{ FINANS } & \multicolumn{2}{|l|}{ Banka } \\
\hline & \multicolumn{2}{|l|}{ Banker } \\
\hline & \multicolumn{2}{|l|}{ Sigorta } \\
\hline \multirow{2}{*}{ YEME-içME-EĞLENCE } & Otel-Lokanta & Gazino-Çalgılı; Otel ve Lokanta \\
\hline & Sinema-Tiyatro & Sinema-Tiyatro \\
\hline \multirow{6}{*}{ PERAKENDE } & Denizcilik & $\begin{array}{l}\text { Gemi Aletleri } \\
\text { Gemi Erzak Tedarik }\end{array}$ \\
\hline & Gıda & Gıda Ürünleri \\
\hline & Giyim & $\begin{array}{l}\text { Deri } \\
\text { Giyim-Moda } \\
\text { Fes } \\
\text { Şapka } \\
\text { Tuhafiyeci }\end{array}$ \\
\hline & Makine/Ev eşyaları & $\begin{array}{l}\text { Dikiş Makinesi Satışı } \\
\text { Gramofon } \\
\text { Halı } \\
\text { Tarım Makineleri } \\
\text { Otomobil }\end{array}$ \\
\hline & Yapı malzemeleri & $\begin{array}{l}\text { Demir Ticareti } \\
\text { Hırdavat-Tuhafiye } \\
\text { Yapı Malzemesi } \\
\text { Boya ve Vernik Ticareti }\end{array}$ \\
\hline & Diğer & $\begin{array}{l}\text { Tüccar } \\
\text { Tütün } \\
\text { Kırtasiye } \\
\text { Konfeksiyoncu }\end{array}$ \\
\hline \multirow{5}{*}{$\begin{array}{l}\text { UZMANLAŞMIŞ } \\
\text { HIZMETLER }\end{array}$} & Denizcilik & $\begin{array}{l}\text { Denizcilik Acentesi } \\
\text { Gemi Ve Sandal } \\
\text { Gemi Zarar Tespit Şirketi } \\
\text { Gemicilik Şirketi } \\
\text { Gümrük Komisyoncusu } \\
\text { Mavna } \\
\text { Remorquages }\end{array}$ \\
\hline & İthalat-ihracat & Hububat İthalatı \\
\hline & $\begin{array}{l}\text { Meslek (uzmanlık } \\
\text { gerektiren) }\end{array}$ & $\begin{array}{l}\text { Avukat } \\
\text { Ayakkabı Tamircisi } \\
\text { Botanist } \\
\text { Ciltleme } \\
\text { Dişçi } \\
\text { Doktor } \\
\text { Eczacı } \\
\text { Kuaför } \\
\text { Kuyumcu } \\
\text { Matbaa } \\
\text { Mimar } \\
\text { Mühendis } \\
\text { Marangoz } \\
\text { Mobilya } \\
\text { Posta Şirketi } \\
\text { Saatçi } \\
\text { Terzi }\end{array}$ \\
\hline & Ticaret & $\begin{array}{l}\text { Fotoğraf } \\
\text { Kolonyal Ürünler } \\
\text { Kartpostal } \\
\text { Piyango }\end{array}$ \\
\hline & Ulaşım & $\begin{array}{l}\text { Demiryolu Şirketi } \\
\text { Seyahat Acentesi }\end{array}$ \\
\hline
\end{tabular}

Tablo 1. Ticari faaliyet alanları. 


\begin{tabular}{|c|c|c|c|c|c|c|c|c|c|c|}
\hline & & 1885 & 1890 & 1895 & 1900 & 1904 & 1909 & 1914 & 1921 & 1930 \\
\hline \multirow{4}{*}{ Patras } & Finans & 8 & 16 & 18 & 20 & - & - & 8 & 6 & 7 \\
\hline & Otel-lokanta & - & 1 & - & - & - & - & 2 & 2 & 10 \\
\hline & Perakende & 4 & - & 9 & 12 & - & - & 1 & 1 & 47 \\
\hline & $\begin{array}{l}\text { Uzmanlaşmış } \\
\text { hizmetler }\end{array}$ & 9 & - & 73 & 37 & - & - & 68 & 40 & 306 \\
\hline \multirow{4}{*}{ Volos } & Finans & 17 & 7 & 5 & 10 & 2 & 2 & 4 & 4 & 7 \\
\hline & Otel-lokanta & 5 & - & - & - & - & - & - & - & - \\
\hline & Perakende & & 8 & - & - & 5 & - & 5 & 5 & 49 \\
\hline & $\begin{array}{l}\text { Uzmanlaşmış } \\
\text { hizmetler }\end{array}$ & 23 & 13 & 8 & 14 & 10 & 2 & 34 & 28 & 407 \\
\hline \multirow{4}{*}{ Mersin } & Finans & 0 & 2 & 4 & 10 & 19 & 15 & 23 & 20 & 5 \\
\hline & Otel-lokanta & 1 & 0 & 2 & 5 & 6 & 4 & 5 & 5 & 14 \\
\hline & Perakende & 8 & 7 & 20 & 23 & 49 & 64 & 84 & 86 & 54 \\
\hline & $\begin{array}{l}\text { Uzmanlaşmış } \\
\text { hizmetler }\end{array}$ & 3 & 8 & 23 & 33 & 60 & 54 & 67 & 77 & 55 \\
\hline
\end{tabular}

Tablo 2. Patras, Volos ve Mersin'deki ticari etkinliğin sektörel dağılımı ve yıllara göre sayısal değişimi.

Ticaret verileri incelendiğinde, her üç kentte de azınlık ve komprador burjuvazinin, ticaretteki etkin aktörler olduğu görülmektedir. Uluslararası deniz ticaretinin yürütülmesinde söz sahibi olan yabancı konsolosluklar hizmet vermeye başlamış, kentin ileri gelen tüccarları, bankerlik yaparak finans sektörünün bu kentlerdeki ilk temsilcileri olmuştur. Örneğin, bağımsızlık öncesinde, henüz Osmanlı egemenliği sürerken, Mora'nın kuzeybatısındaki arazileri ile büyük bir güç haline gelen Papadiamantopoulos, bankerlik ve ardından denizcilik alanındaki faaliyetleri ile Karadeniz kıyılarından Hollanda ve İngiltere'ye kadar uzanan denizaşırı ticari ilişkiler geliştirmiştir. Papadiamantopoulos, arazi sahipliğinden gelen sermayenin, denizciliğe dayalı ticari faaliyetlere aktarılması ve kentte bir ticaret burjuvazisinin gelişmeye başlamasının da somut bir örneğidir. ${ }^{34}$ Benzer biçimde, Mersin'de finans sektörünün henüz kurumsallaşmadığı ve bankaların bulunmadığı dönemde, kentin önde gelen tüccarlarından Constantin Mavromati, "Christmann ve Mavromati Oğulları" adında bir yazıhane açarak, o dönemde pek çok sarrafın yaptığı gibi borç verip almakta ve finansal işler yapmaktadır. ${ }^{35}$

Bu dönemde, Patras'ta, bir yandan sigorta acenteleri açlıp avukatlar hizmet verirken öte yandan, bankerlerin ve aralarında Nationale Bank de Greece'in de olduğu banka şubeleri açılmaktadır. ${ }^{36}$ Volos da Teselya Ovası'ndaki kent ve köylerle bağlantısını sağlayan demiryolu ağının inşası ve limanın iyileştirilmesine yönelik girişimler sonrasında, ticari açıdan oldukça hareketli bir merkez haline gelmiş, çok sayıda konsolosluk, sigorta acenteleri, avukatlar ve bankalar kentsel mekandaki yerlerini almıştır. ${ }^{37}$ Mersin'de ise, özellikle iskele ve istasyon arasindaki bölgede yer alan tüccar hanlarında, toptancılar, komisyoncular, sigorta şirketleri faaliyet gösterirken, yakın çevrede Ziraat Bankası, Osmanlı Bankası,

34 Municipality of Patras, Haritalar ve Hatıralar 1813-1943, 109-110.

35 Osmanlı Şark Ticaret Yillığ (1894), 929.

36 Annuaire Oriantal du Commerce (1890), 869.

37 Annuaire Oriantal du Commerce (1889-1890), 874. 
Deutsche Orientbank, Atina Bankası, Selanik Bankası gibi bankalar hizmet vermeye başlamıştır. ${ }^{38}$

Ticari etkinliğe bağlı olarak artan iletişim gereksinimiyle, her üç kentte de postane ve telgraf ofisi gibi yeni kullanımlar kendini göstermiştir. Volos'ta 1863 yılında Selanik'e bağlanan bir telgraf hattı kurulmuş ve kale ile yeni gelişen şehir arasındaki ticaret meydanında telgraf ofisi açılmıştır. ${ }^{39}$ Benzer biçimde, 1868 yılında, Adana'dan Tarsus'a kadar döşenen telgraf hattının Mersin iskelesine dek uzatılmasına karar verilmiş ve 1873 yılında kentte, bir telgraf ve posta idaresi kurulmuştur. ${ }^{40}$

1900'lü yıllara kadarki dönemde, limandaki ticari hareketliliğe dayalı, kentsel mekândaki bu hızlı gelişimde, geçmişteki mekânsal yapıdan tamamen farklı yeni kentsel alanların oluştuğu görülmektedir. Bu aşamada Patras ve Volos'ta, mevcut kentsel dokuya yeni bir kentsel alan eklenirken, Mersin'de ise kıyıda, tamamen yeni bir kentsel alan şekillenmeye başlamıştır.

Patras, 19. yüzyıl öncesinde, denizle ve kıyıyla doğrudan ilişkisi olmayan, Patraikos Körfezi'ne yukarıdan bakan, kale içindeki organik yerleşim dokusu ile 1800'lü yılların başında oldukça mütevazi bir Osmanlı kentidir. Volos da Pagasitikos Körfezi'nde, küçük bir kale ve kıyıdaki birkaç küçük dükkân ve depodan oluşan, halen Osmanlı egemenliğindeyken, Rum tüccarların talepleriyle bir liman kentine evrilmeye başlayan bir başka Osmanlı kentidir. Mersin ise bu dönemde, Tarsus'taki konsolosların, merkezi hükümete, yeni bir liman olarak önerdikleri birkaç iskeleden ibarettir.

Ancak her üç kentte de gelişen ticaret ve iş olanakları sonucu farklı nüfus gruplarının gelip yerleşmesiyle kentsel yerleşik alan genişlemeye başlamıştır. 1885 yılında, 38.000 kişilik nüfusa sahip Patras'ta ağırlıklı olarak Ortodoks Rumlar olmak üzere, Müslüman Türkler ve Yahudiler yaşarken, ${ }^{41} 14.000$ kişilik nüfusuyla Volos'ta, Müslüman Türk nüfusun yanı sıra, Ortodoks Rumlar, Katolik Avrupalılar ve Yahudiler yaşamaktadır. ${ }^{42}$ Yalnızca 6.000 nüfuslu ${ }^{43}$ Mersin'de ise Avrupalı Katolikler (Levantenler), Ortodoks Araplar, Müslüman Türkler, Yahudiler, Ermeniler ile Maruni, Süryani, Keldani, Nusayri gibi gruplar yaşamaktadir. ${ }^{44}$

Nüfusun artışıly birlikte, Patras'ta, 1820'li yıllardan itibaren, kale ve çevresindeki mevcut yerleşik alan dışında, kıyıda yeni bir kentsel alan gelişmeye başlamıştır. Benzer biçimde Volos'ta da kale içindeki mevcut yerleşimin dışında, doğuda yalnızca ticari kullanımların yer aldığı bir ticaret bölgesi gelişmiştir. Dolayısıyla 1840 'lı yıllarda, Volos'ta kentsel yapının parçaları, kale içindeki konut alanı, kalenin güneyindeki liman bölgesi ve batıda yeni gelişen ticaret alanıdır. Dolayısıyla, Patras'ta ve Volos'ta, kentsel mekân bu ilk aşamada, eski ve yeni şehirden oluşan ikili bir yapı ile gelişmiştir.

Mersin'de ise Patras ve Volos'tan farklı olarak, geçmişten gelen mevcut bir kentsel yerleşim olmadığı için tamamen yeni bir kentsel gelişim söz konusu

38 Ünlü, “19. Yüzyılda Mersin'in Kentsel Gelişimi”, 211-214.

39 Vilma Hastaoglou-Martinidis, "Foundation and Evolution of the New City During the 19th Century", Volos 1881-1955: The City and the People içinde (Volos: DIKI, 2004), 52.

40 Ünlü, “19. Yüzyılda Mersin'in Kentsel Gelişimi”, 172-174.

41 Malcolm Wagstaff ve Elena Frangakis-Syrett, "The Port of Patras in the Second Ottoman Period: Economy, Demography and Settlements c. 1700-1830", Revue des mondes musulmans et de la Méditerranée 66, no. 1 (1992): 85.

42 Hastaoglou-Martinidis, Volos: Portrait of the City from the 19th Century to Today, 72.

43 Indicateur Oriental (1885-1886), 478.

44 Ünlü, “19. Yüzyılda Mersin'in Kentsel Gelişimi”, 85-92. 
olmuştur. Gelişen bu kentsel alan, doğrudan iskeleler ve denizle ile ilişki içinde, kıyıya paralel bir cadde etrafında, konut ve ticaretin bir arada olduğu tekli bir yapıyla şekillenmiştir (Şekil 3).

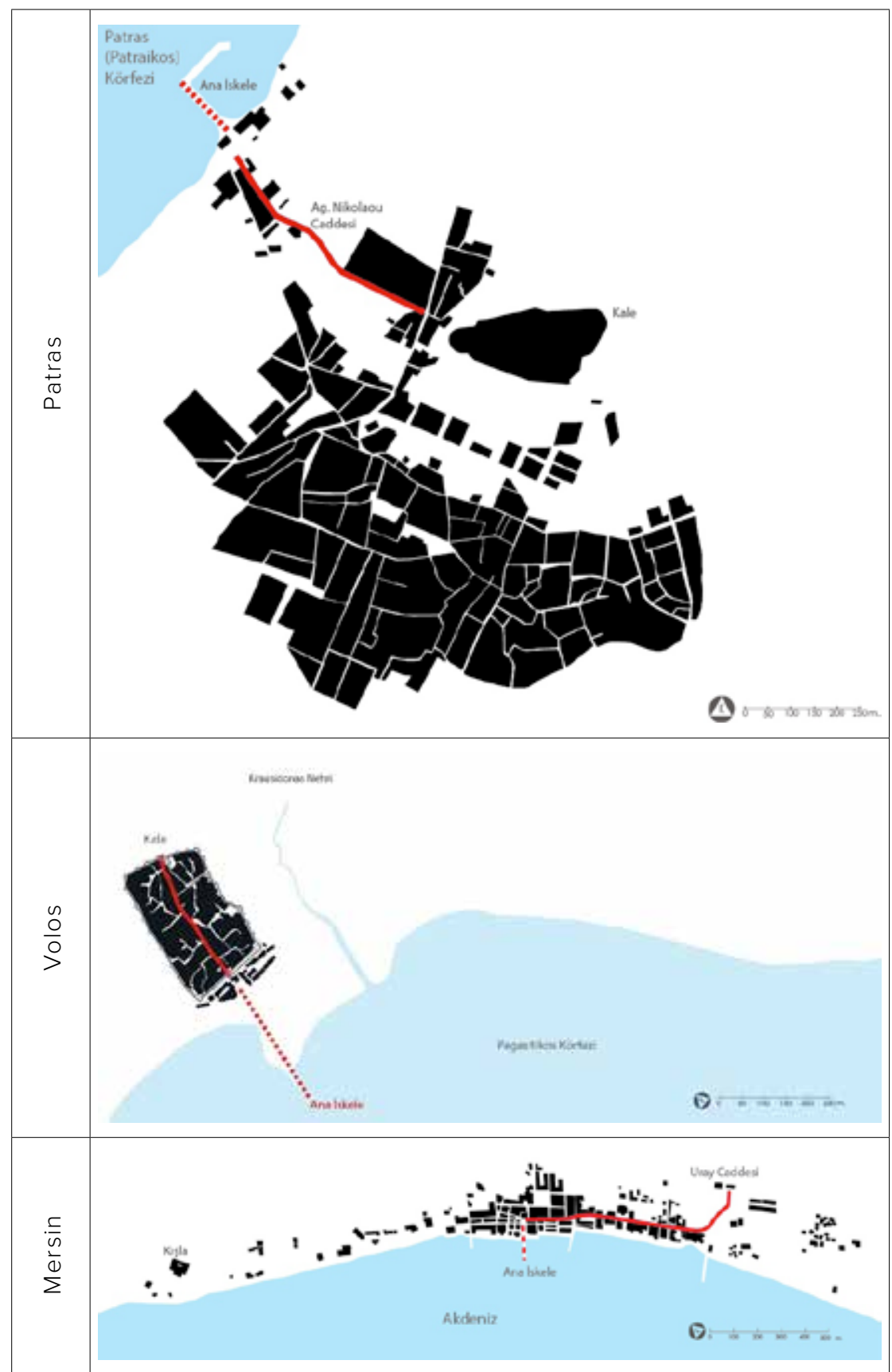

Şekil 3. İlk aşamada, Patras, Volos ve Mersin'de kentsel mekân. 


\section{Íkinci Aşama}

1900'lü yıllara kadarki dönemde her üç kentte de denizle ilişki içinde ve kıyıyı referans alan bir mekânsal gelişim izlenmektedir. Her üç kent için de henüz kıyı çizgisine herhangi bir müdahale olmamıştır ve kent-deniz ilişkisini kuran yollar, ortaklaşan mekânsal bileşendir. Patras'ta kent-deniz ilişkisini kuran ve deniz/kale gibi önemli referansları olan Ag. Nikolaou Caddesi; Volos'ta, kale içinde dağ-deniz doğrultusundaki yol (Osmanlı döneminde Larissa ve deniz bağlantısını sağlayan ana cadde) ve yeni gelişen kentteki ana iskeleye açılan Iolku Caddesi ve Mersin'de ise istasyon ve kentin ana iskelesini birbirine bağlayan Uray Caddesi denizi esas alan mekânsal kurguya işaret etmektedir.

Patras ve Volos'un birer liman kentine evrilmesi ve Mersin'in ise yepyeni bir liman kenti olarak ortaya çıkmasını sağlayan değişimler, her üç kentte de yerelin gereksinim ve talepleriyle, noktasal müdahale ve düzenlemelerle, herhangi bir plana dayalı olmadan gerçekleşmiştir. Oysa, birer Osmanlı kenti olan Patras, Volos ve Mersin, Yunan devleti ve Türkiye Cumhuriyeti'nin kuruluşuyla birlikte, iki farklı ulus-devletin sınırları içinde yer almış ve bu aşamadan itibaren kentsel mekânın gelişiminde planlı dönem başlamıştır.

Yunan devleti sınırlarına dahil olan Patras ve Volos ile Türkiye Cumhuriyeti devleti sınırları içinde yer alan Mersin için, kurulan bu yeni devletlerin, kentsel mekânın yeniden düzenlenmesine yönelik müdahaleleri, yeni bir mekânsal gelişim biçimini beraberinde getirmiştir. Patras'ın 1829 yılındaki ilk planı, kentin Yunan devleti sınırları içine dahil olmasından yalnızca bir yıl sonra, Paris'te mühendislik eğitimi gören Stamatis Voulgaris tarafından hazırlanmıştır. ${ }^{45}$ Voulgaris'in planı, kale surları ve etrafındaki eski (yukarı) şehri yeniden düzenlerken, deniz kıyısında ticaretin merkezi olarak hızla gelişen yepyeni bir kent kurmayı öngörmüştür. ${ }^{46}$ Geometrik formlar ve simetrik bir kurgunun benimsendiğ $\mathrm{i}^{47}$ söz konusu plan bir anlamda, 19. yüzyılın Batı'daki modernist şehircilik yaklaşımının erken dönem örneklerinden biri olmuştur.

Patras'ta olduğu gibi Volos'un da ilk planı, kentin Yunan egemenliğine geçmesinden yalnızca bir yıl sonra, 1882 tarihinde hazırlanmış; Volos, Yunan otoritelerince Teselya bölgesinde planı yapılan ilk kent olmuştur. Söz konusu plan, 1844 yılında gelişmeye başlayan yeni şehirdeki izleri devam ettiren ve ızgara dokuyu esas alan bir plandır. Basit, dik açılı sokaklar ve birbirinin aynı yapı adalarından oluşan yeni yerleşimi ve kaleyi de içine alan bu planla ${ }^{48}$ kale ve kalenin doğusunda gelişen yeni şehrin bütünleştirilmesi ve yeni bir kentsel yapının oluşturulması hedeflenmiştir. Planın, Haussmann etkisi ile Avrupa'da 1zgara planın yaygın olarak uygulandığ1 dönemin eğilimleri ${ }^{49}$ ile örtüştüğü ve geçmişin izlerini ortadan kaldırarak, kurulan ulus-devletin yeni ve modern kentini yaratmayı amaçladığı izlenmektedir. Öyle ki, bu plan ile zaman içinde kale içindeki Osmanlı dokusu tamamen ortadan kalkmış, ızgara plan bu alanda da uygulanmıştır. ${ }^{50}$ Dolayısıyla Volos'ta, ulus-devletin modernite proje-

45 Vilma Hastaoglou-Martinidis, Kiki Kafkoula ve Nicos Papamichos, “Urban Modernization and National Renaissance: Town Planning in 19th Century Greece", Planning Perspectives 8, no. 4 (1993): 432-433.

46 Municipality of Patras, Haritalar ve Hatıralar 1813-1943, 127-8.

47 E. Gatopoulou, "Kentsel Planlama, Kentsel Altyapı, Mimarlık, Anıtlar (19 ve 20. Yüzyıllar)”, Antik Dönemden Günümüze Patras içinde, derleyenler T. E. Sklavenitis ve K. Staikos (Atina: Kotinos, 2005), 295 (Yunanca).

48 Dimoglou ve Mourtzoukos, Volos then \& now, 146.

49 Leonardo Benevolo, Avrupa Tarihinde Kentler, çev. Nur Nirven (İstanbul: Literatür, 2006).

50 Vilma Hastaoglou-Martinidis, Volos: Portrait of the City from the 19th Century to Today, 65. 
sinin, geçmişten kopuşu hedefleyen uygulamalarındaki belki de en yıkıcı yanı, söz konusu mekânsal müdahalede somut olarak kendini göstermiştir. Kurulan Yunan Devleti'nin ilk mekânsal müdahaleleri olarak gerek 1829 Patras planı, gerekse 1882 Volos planı, yukarı ve aşağı şehir olmak üzere iki parçadan oluşan kenti, 1zgara dokuyu esas alan bir kurguyla bütünleştirmeyi amaçlamıştır.

Tarih olarak Patras ve Volos'tan sonra olmakla birlikte Mersin için de kentsel mekâna ilk planlı müdahale girişimi, 1923 yılında Türkiye Cumhuriyeti'nin kurulması sonrasında gerçekleşmiştir. Mersin'de, Patras ve Volos'tan farklı olarak kentsel mekân ikili bir yapıyla gelişmese de zaman içinde, sermaye birikimiyle birlikte, kentsel mekânda sınıfsal farklılaşmaya işaret eden yeni konut alanları kendini göstermiş, kentin batısında, ticaret burjuvazisine ait yeni bir kentsel alan şekillenmiştir. 1938 yılında Alman şehirci Hermann Jansen tarafından hazırlanan planla, kentin işlevsel olarak ayrışan bu iki alanı arasındaki ilişki güçlendirilmeye çalışılmış, böylece doğudaki ticari merkez ile batıdaki yeni konut alanının bir kentsel bütün oluşturması amaçlanmıştır. Jansen'in planında oluşturulan yeşil koridorların denize açılması ve denizle kentin ilişkisinin sürdürülmesi yönünde bir yaklaşım geliştirilmiştir. ${ }^{51} \mathrm{Bu}$ çabanın en somut ifadesi ise tıpkı Voulgaris'in Patras'ta öngördüğü gibi, kıyı boyunca tasarlanmış olan "sahil promenadı"dır.

Ancak, Camillo Sitte ekolünden gelen Jansen'in, Mersin için hazırladığı bu plan, Paris'te eğitim almış Voulgaris'in Patras planından da Haussman'ın planlama yaklaşımını benimseyen Volos planından da farklılaşmıştır. Dolayısıyla, her üç kente yönelik mekânsal planlama eylemi, modernist planlamanın farklı yaklaşımlarını esas almıştır. İç avlulu adaları ile klasik Yunan ızgara sistemini çağrıştıran Patras planı, militarist Haussmann anlayışı ile örtüşen Volos planı ve bir bahçe-kent modelini kurgulayan Mersin planı, modernite projesinin, benzer hedeflerine karşın, farklı bağlamlardaki kentsel mekânlara yönelik fark11 yaklaşımları yansıtmıştır (Şekil 4).

Dolayısıyla kurulan iki ulus-devletin de kentsel mekâna planlı müdahalelerde bulunduğu ve hazırlanan planlar ile eski ve yeni dokuyu birleştiren homojen bir kentsel bütün oluşturulmaya çalışıldığı görülmektedir. Ancak hazırlanan planlar, her ne kadar geçmişin izlerini silme ve yeni bir kentsel mekân yaratma idealini gerçekleştirme eylemi olarak yola çıkmış olsa da söz konusu kentlerin geçmişten gelen liman işlevi ve bu işlev doğrultusunda şekillenmiş parça-bütün ilişkisini güçlendirmeye yönelik yaklaşımları benimsediği izlenmektedir. Ancak bu durum Volos'ta, Patras ve Mersin'den farklılık göstermektedir. Çünkü Volos için hazırlanan 1882 planı, kale içindeki eski dokunun tamamen ortadan kaldırılmasının öngörüldüğü, Patras ve Mersin'den farklı olarak daha radikal olarak "geçmişten kopuşun" benimsendiği bir planlama anlayışını yansitmaktadır.

Yine de bu aşamada, her üç kent için de hazırlanan söz konusu planlar, kentsel parçalar arasındaki ilişkiyi güçlendirmeyi ve bir bütün oluşturmayı hedeflemiş, bunu yaparken de pragmatik bir yaklaşımla, geçmişten gelen kurulu işlevsel ilişkiyi ortadan kaldırmak yerine yeniden düzenlemişlerdir. Bir başka deyişle, değiştirilmesinin getireceği riskler nedeniyle, kentin birinci aşamada temel kurgusunu oluşturan işlevsel, kemikleşmiş izler ve mevcutta işleyen

51 Tolga Ünlü ve T. Levent, “Mersin'de Kentsel Mekanın Biçimlenmesinde Jansen Planı́nın Etkileri", Tarih İçinde Mersin Kolokyum II içinde, derleyen Tülin Selvi Ünlü (Mersin: Mersin Üniversitesi, Akdeniz Kent Araştırmaları Merkezi Yayınları, 2005); Tolga Ünlü, “Mekansal Planlamanın Kentin Biçimlenmesine Etkisi: Mersin Örneği", Planlama 2009, no. 3-4 (2009): 27-42. 
kurulu ilişkileri kaldırmak yerine, bunları yeniden düzenleyerek kullanmak tercih edilmiştir. Burada, yeni ulus-devletlerin kurumsal, finansal ve organizasyonel yetersizliklerinin de etkili olduğuna kuşku yoktur.

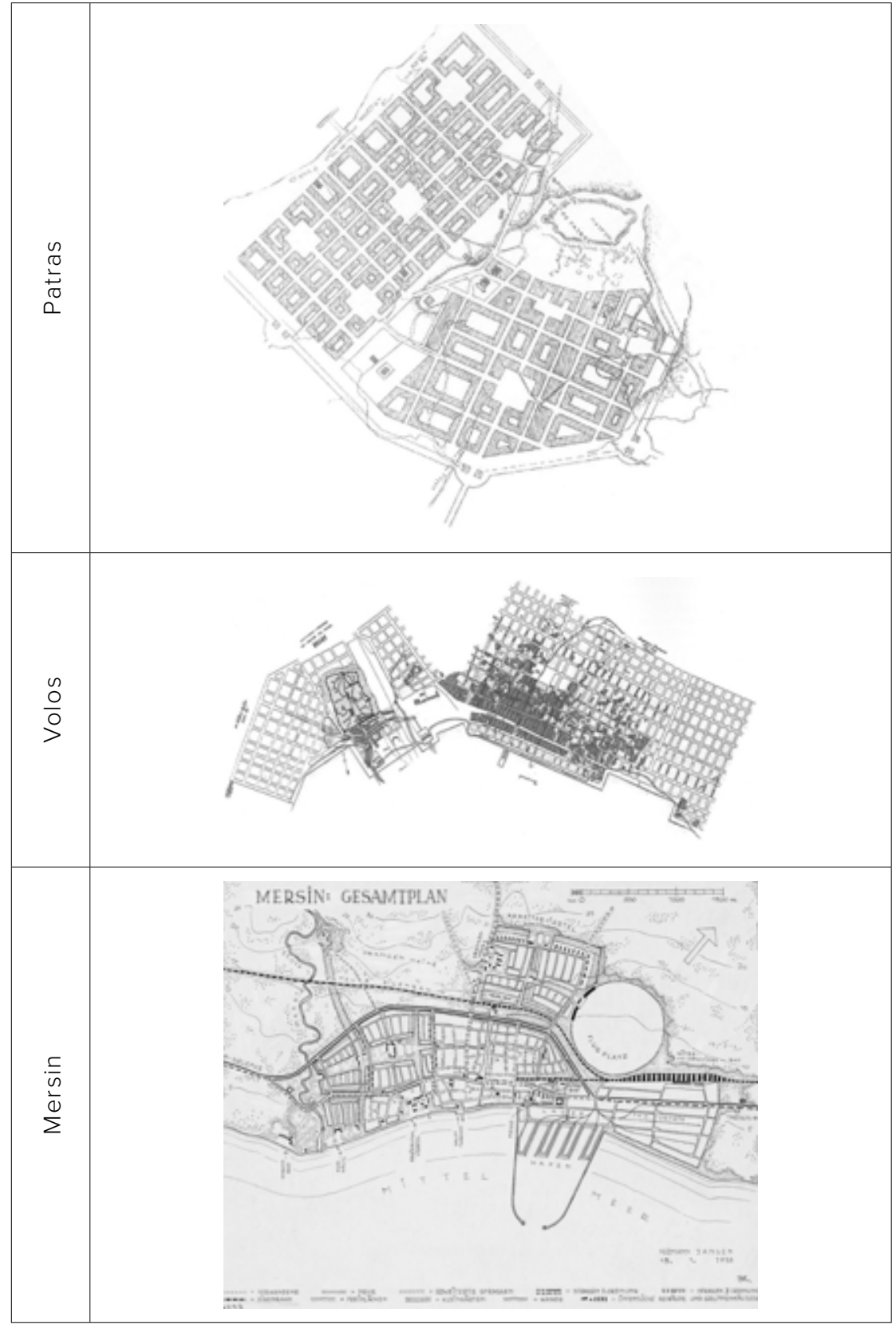

Şekil 4. Volos 1882 planı (Hastaoglou-Martinidis, Volos: Portrait of the City from the 19th Century to Today, 54), Patras 1829 planı ve Mersin 1938 plan1 (Architekturmuseum der Technischen Universität Berlin, 2010). 
Ulus-devletin kentsel mekânı yeniden düzenlemeye yönelik giriştiği bu eylemlerin beklenen düzeyde gerçekleşmemesi ve radikal değişimlere yol açmamasındaki bir diğer önemli neden ise kapitalist ekonomi ve sermayenin, bu kentlerde kurguladığı, hızla dönüştürülmesi güç, köklü ve kentsel pratiklere dayalı, mekânsal yapı ve izlerdir. Söz konusu yapı ve izler, sermayenin öncelikleri ve beklentileri doğrultusunda, temelde liman işlevine ve ticarete dayalı mekânsal ilişkiler ve kentsel yaşam pratikleriyle, süreç içinde gelişmiş ve birbiriyle güçlü işlevsel bağları olan bir kentsel yapı üretmiştir. ${ }^{52}$

Henüz kimlik ve karakterinde köklü bir değişim yaşanmamış olmakla birlikte, her üç kentte de ulusal köklere referans veren yeni mimari dili yansitan yapılar yavaş yavaş kendini göstermeye başlamıştır. Kurulan ulus-devletler, kendi modernite projeleri doğrultusunda, ulusal köklerine referans veren yeni bir mimari dili görünür kılmaya çabalamışlardır. Her iki ulus için de Osmanlı'dan kopuşa işaret eden bu yaklaşım, özellikle kamusal yapılarla kendini göstermiştir. Oluşturulmaya çalışılan yeni kent imgesinde, Volos'da Achilleion Tiyatrosu, Patras'ta Apollon Tiyatrosu ve Mersin'de ise Halkevi binası, modernleşmenin en önemli simgesel karşılıkları olarak kentsel mekândaki yerlerini almışlardır.

Ancak ulus-devletlerin kuruluşunun hemen ardından gelen ve her ne kadar eskiden kopuşu hedeflese de kentlerin denizi esas alan, ilişkisel mekânsal kurgularını, büyük ölçüde sürdüren ve yalnızca simgesel, noktasal müdahalelerin gerçekleştiği 1900'lü yıllar ile 1940'lı yıllara kadarki dönemde, henüz kentsel mekânda köklü bir değişimden söz etmek güçtür.

\section{Üçüncü Aşama}

Ancak 1940'l1 yıllardan itibaren, her üç kent için de ulus-devlet modernleşmesinin müdahalelerinin kapsamlı sonuçları artık kendini göstermeye başlamıştır. Patras'ta, kentin ticari merkezinde önemli bir değişim olmazken, geçmişten beri gümrük iskelesi olan Ag. Nikolaou İskelesi işlev değiştirmiş ve buradaki gümrük binası yıkılarak, yeni yapılan Kalavryta İskelesi'ne taşınmıştır. Böylece, kentin ticari etkinliği Kalavryta ve sonradan yapılan Ag. Andreas İskelesi'nde sürerken, Ag. Nikolaou İskelesi yolcu trafiği için kullanılmaya başlamıştır.

Volos'ta ise eski ve yenişehir arasında doğal bir eşik oluşturan Krausidonas Nehri yatağının kalenin batısına alınması, kale surları ve kale içindeki organik dokunun tamamen yıkılması gibi uygulamalarla eski ve yeni şehir birleştirilmiş ve hedeflenen homojen kent bütünü sağlanmıştır. ${ }^{53}$ Öte yandan, kalenin doğusunda gelişen yeni şehrin iskelesi genişletilmiş, ticari etkinlik körfezdeki eski limanda toplanmış ve söz konusu iskele artık yolcu limanı olarak kullanılmaya başlamıştır. İskelenin değişen kullanımıyla birlikte, Argonafton Caddesi, kafe, restoran ve otellerle birlikte önemi giderek artan bir kamusal mekân haline gelmiştir. ${ }^{54}$ Dolayısıyla Volos'ta, artık bir yük iskelesi olmaktan çıkan yeni şehrin ana iskelesinin değişen işleviyle, kıyıdaki ticari kullanımlar yerini, sosyal ve kültürel kullanımlara bırakmaya başlamıştır.

Mersin'de ise 1955 yılında başlayan yeni liman yapımı sırasında, kıyıda geniş bir dolgu yapılmıştır. Dolgu, kenti denizden uzaklaştırmakla kalmamış,

52 Dokuz Eylül Üniversitesi, Şehir ve Bölge Planlama Bölümü, Habitat II Dünya Deneyimleri Kapsamında İzmir Bağlamına Nasıl Bakılabilir: Bir Gelişmenin Anatomisi (Yayınlanmamış Çalışma, İzmir, 1996).

53 Vilma Hastaoglou-Martinidis, "Foundation and Evolution of the New City During the 19th Century", Volos 1881-1955: The City and the People içinde (Volos: DIKI, 2004), 43-60.

54 Dimoglou ve Mourtzoukos, Volos then $\mathcal{E}$ now, 147. 
iskelelerin yıkımıyla, iskeleler ve uzantısındaki işlevsel kurguyu da ortadan kaldırmıştır. Kentin ana iskelesinin ve uzantısındaki gümrük binasının yıkılmasıyla, bu alanda geçmişten beri bir ticaret meydanı olan Gümrük Meydanı tanımsız ve işlevsiz bir hale gelmiştir. Öte yandan, kıyıdaki iskelelerle ve Gümrük Meydanı'yla bağlantılı olan, Uray Caddesi ve çevresindeki ithalat-ihracata yönelik ticari yapılar zaman içinde işlevlerini kaybetmiştir. İlerleyen dönemde, dolgu alanından geçirilen karayolu ise deniz ve kent ilişkisinde bir engel olarak belirmiştir (Şekil 5, 6, 7).

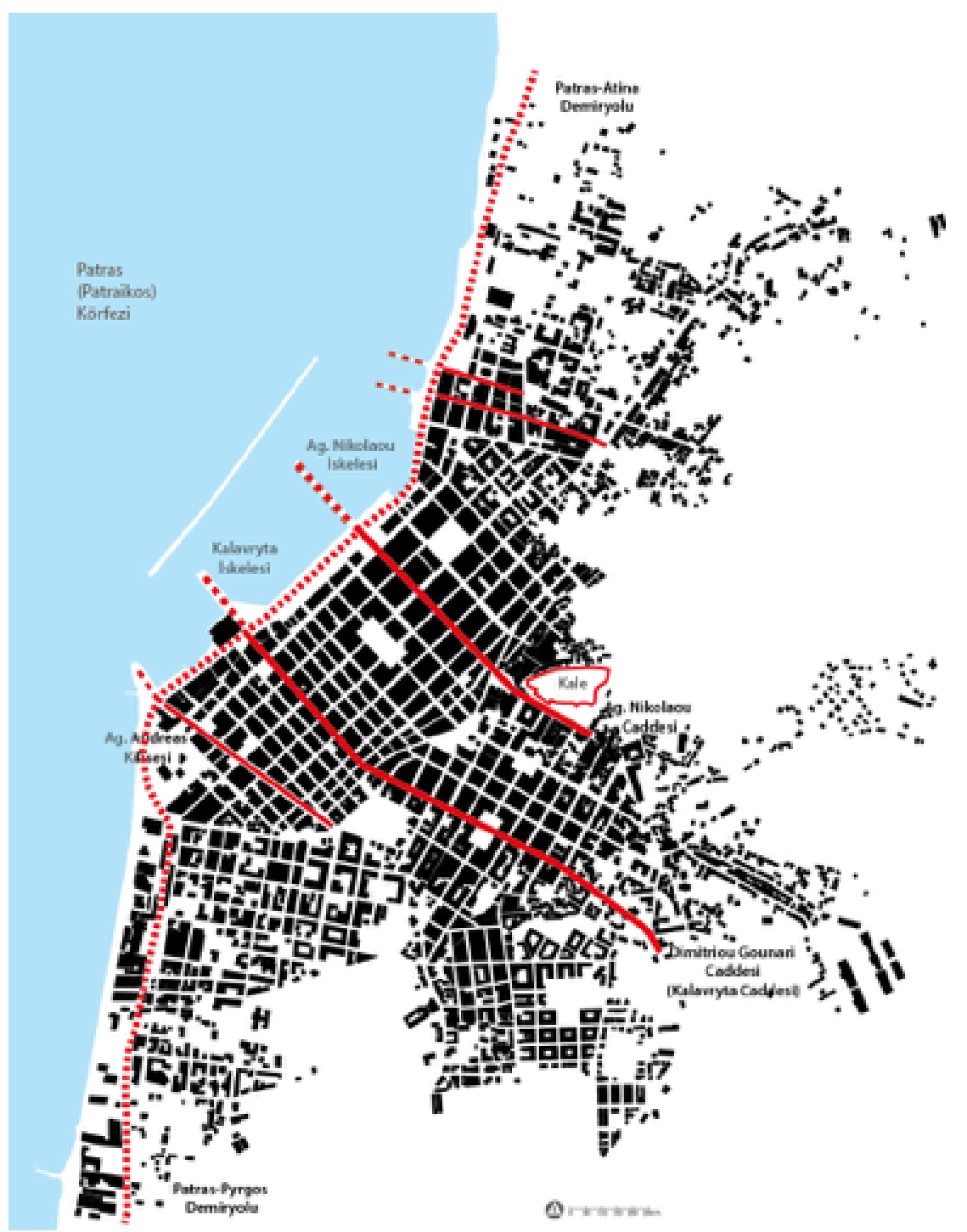

Şekil 5. 1940'l1 yıllarda Patras'in mekânsal kurgusu (ELIA-Athens Arşivi'ndeki 1944 tarihli İngiliz haritası üzerinden üretilmiştir). 


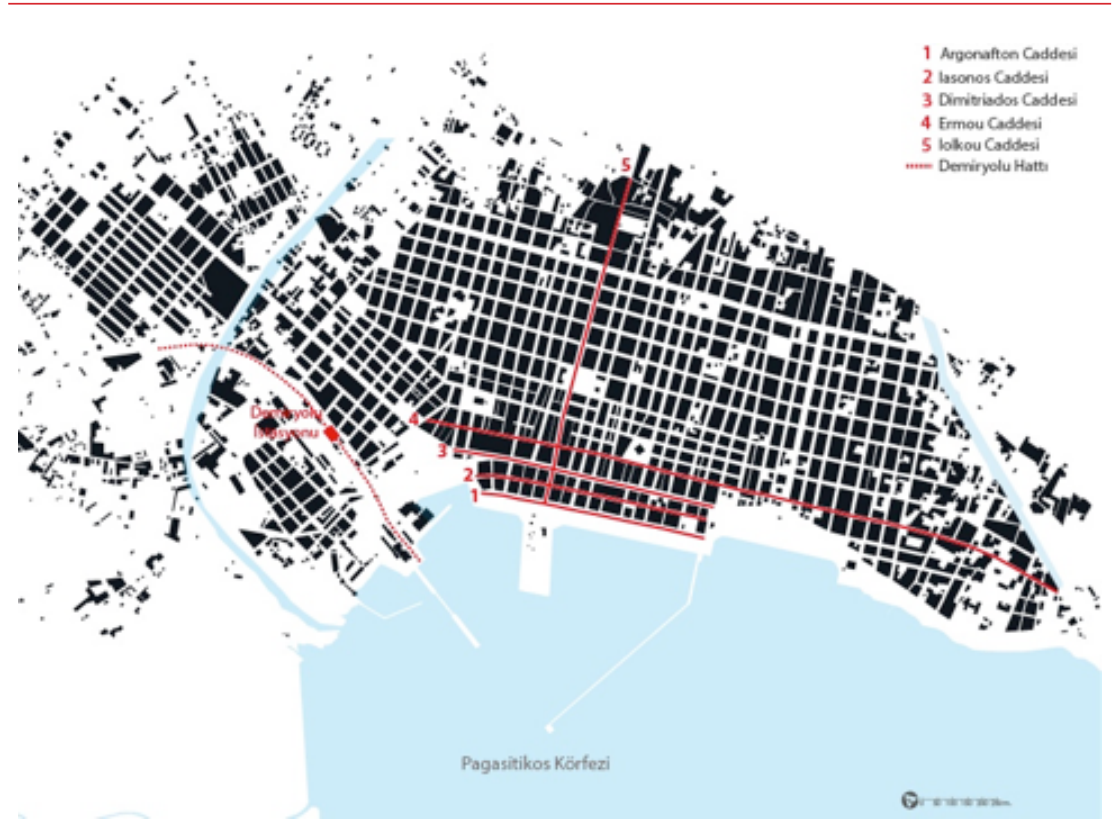

Şekil 6. 1940'lı yıllarda Volos'un mekânsal kurgusu (ELIA-Athens Arşivi'ndeki 1942 tarihli İngiliz haritası üzerinden üretilmiştir).

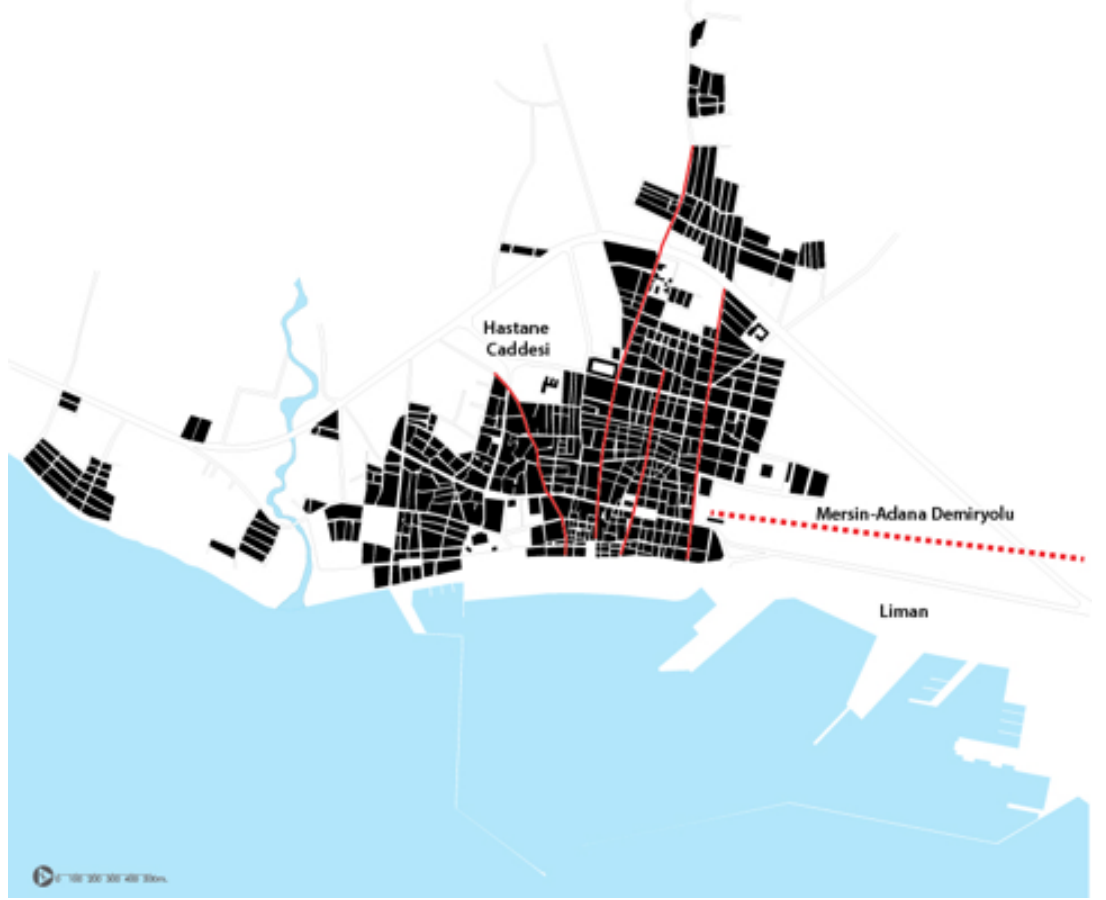

Şekil 7. 1960'larda Mersin'in mekânsal kurgusu (L. Rother, Die Städte der Cukurova: Adana-Mersin-Tarsus [Tübingen: Geographisches Instituts der Universität Tübingen, 1971], 219'daki haritadan üretilmiştir). 


\section{Değerlendirme}

Kentlerin sahip oldukları kimlik ve karakteri sürdürebilmesi için, kentsel mekânda, kendi içinde sorunsuz işleyen parçalar kadar, bu parçaların bir araya gelmesini sağlayan kurgu ve bütün ile ilişkisi de önemlidir. ${ }^{55}$ Dolayısıyla, “Doğu Akdeniz liman kenti"ne özgü nitelikler, söz konusu kentlerin, Akdeniz coğrafyası ile kurdukları ilişkide ve bu kentlerin kendi iç mekânsal kurgusunda aranabilir. O halde, Doğu Akdeniz'de, üst ölçekteki benzer süreçlerle birer liman olarak gelişen bu kentlerin, mekânsal biçimlenişinde etkili olan süreç, aktör ve bileşenler ile bunların ne tür ortaklık, benzerlik ya da farklılar ürettiğine bakmak gereklidir.

Akdeniz liman kentlerine ilişkin çalışmalarda, söz konusu kentlerde, farklı dini inançlar ve bunların mekânda yerini alan yapıları, denizle ilişki, iklim, liman ve ticaret gibi bu coğrafyanın doğasından kaynaklanan benzer koşullarla şekillenen mekânsal yapının benzerliği dikkat çeker. Gerek daha önce yapılan çalışmalar gerekse bu çalışmada incelenen örnekler dikkate alındığında, liman, mendirek, rıhtım, sahil promenadı, ana iskeleye açılan ve ticari etkinliğin odağı olan cadde, demiryolu, demiryolunun ana istasyonu ile bu cadde ve liman arasındaki güçlü ilişki söz konusu kentlerin ortaklaşan yapısal özellikleri olarak karşımıza çıkar.

İncelenen örnekler dikkate alındığında söz konusu kentlerin, 19. yüzyıldaki yeni ekonomik yapılanmanın yarattığı benzer koşullarda, temel olarak denizle kurdukları ilişki ve kendi bağlamları doğrultusunda, üç aşamalı bir bir sosyo-mekânsal gelişim ve değişim geçirdiği izlenir. İlk aşamada, söz konusu kentlere uluslararası sermaye girmiş, deniz ticaretine ve liman etkinliğine dayalı yeni bir kentsel yapı oluşmuştur. İkinci aşamada, uluslararası sermaye, başta ulaşım altyapısı olmak üzere çeşitli yatırımlarla kentsel mekânda yerleşmiş ve liman kenti kimliğini geliştirecek şekilde kentsel yapı güçlendirilmiştir. Üçüncü aşamada ise ulus-devletlerin etkisi kendini göstermiş, kentsel mekâna yönelik yeni uygulama ve müdahaleler söz konusu olmuştur.

\section{Süreçlerde Değişim}

19. yüzyıldan 20. yüzyıl başına, Doğu Akdeniz liman kentlerinde, ilk iki aşamada kentsel mekânın biçimlenişi, ticari etkinlik ve yerel aktörlerce belirlenen mekânsal deneyimlerle (bağlam bağımlı); yerelin talep ve gereksinimleri doğrultusunda aşağıdan yukarıya doğru; süreç içinde gelişen parça-bütün ilişkisi ile (kendiliğinden) ve evrimsel olarak gerçekleşirken üçüncü aşamada; planlar ile yukarıdan aşağı doğru, bütün oluşturmaya dönük bir yaklaşımla biçimlen(diril)miştir.

\section{Yapılı Çevrede Değişim}

Bu aşamaların kentsel mekânda yarattığı değişim açısından ise ilk iki aşamada, ticaretin gelişmesi ve sermaye girişiyle birlikte yeni bir kentsel yapı kendini göstermiştir. İkinci aşamada, ticari kapasitenin ve kârın artırılmasına yönelik olarak kentsel mekânda, özellikle yabancı sermaye tarafından, liman, rıhtım, demiryolu gibi kalıcı yatırımlar gerçekleşmiştir. Liman kenti kimliği ve karakterini güçlendiren müdahalelerin gerçekleştiği bu aşama, aynı zamanda ulus-devletlerin kurulduğu dönemdir ve mekâna ilk planlı müdahaleler de bu aşamada gündeme gelmiştir. Ancak bu müdahaleler, geçmişten gelen kentsel yapıda önemli bir değişim yaratamamıştır. Bunda, kurulan yeni ulus-devletlerin finansal ve kurumsal yapılarının henüz yeterince güçlü olmaması kadar,

55 Kevin Lynch, A Theory of Good City Form (Massachusetts: MIT Press, 1981). 
söz konusu kentlerin, yerelin kendine özgü bağlamı içinde ve kentsel yaşam pratikleri doğrultusunda şekillenen mekânsal yapısının oluşturduğu direnç de etkili olmuş görünmektedir.

Ancak üçüncü aşamada, aşağıdan yukarıya doğru, yerelin kendi dinamikleri ve mekânsal pratikleriyle şekillenmiş kentsel yapısı değişmeye başlamıştır. Bu kentlerin mekânsal gelişimi artık, ulus-devletin modernite projesinin öncelikli uygulama alanlarından biri olarak resmi otoritelerce hazırlanan planlarla yönlendirilmiştir (Şekil 8).

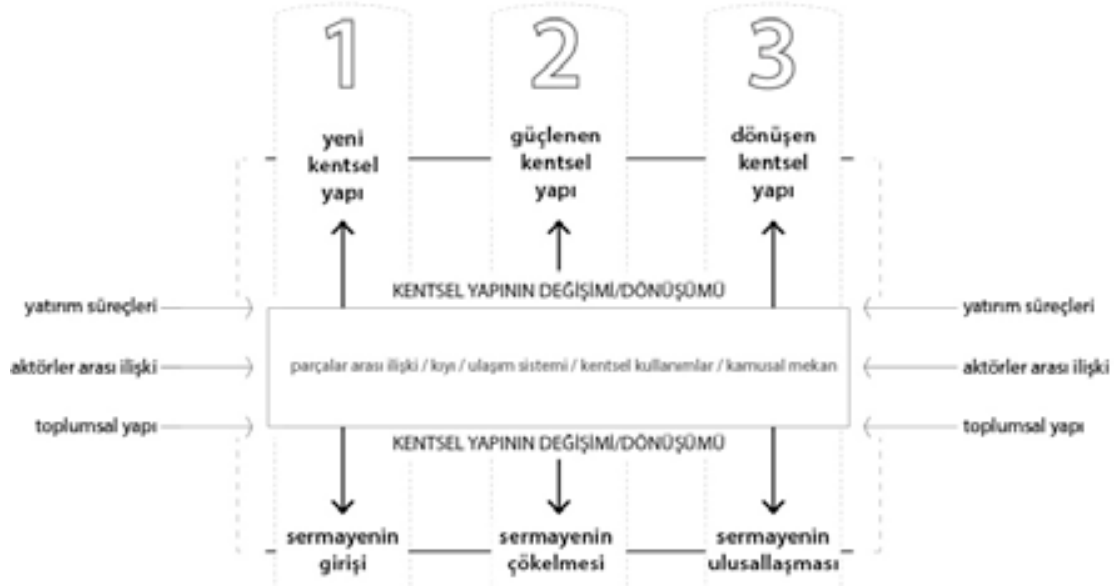

Şekil 8. Doğu Akdeniz liman kentlerinde, mekânsal gelişim süreçleri ve dönemleri arasındaki ilişki.

Dolayısıyla, dönem rasyonelleri, büyüme dinamikleri ve mekânsal gelişimleri açısından üç aşamalı bir değişim ve dönüşüm yaşayan Doğu Akdeniz liman kentleri, ilk iki aşamada, kapitalist üretim ilişkilerince belirlenen rasyoneller doğrultusunda gelişmiş ancak mekânsal yapı, yere ve bağlama özgü koşulların etkili olduğu bir süreçle biçimlenmiştir. Çünkü kapitalist üretim biçim ve ilişkilerinin, karın artırılmasına yönelik temel talebi doğrultusunda, liman işlevi ve denizle ilişkiyi güçlendiren bir mekânsal gelişim söz konusu olmuştur.

İkinci aşama bu kentlerin, içinde yer aldığı bağlam doğrultusunda, liman kenti kimliğini güçlendiren iktisadi süreçler ve ortak mekânsal bileşenlerle şekillendiği aşama olmuştur. Ancak ulus-devletlerin kurulmasıyla, mekâna çeşitli müdahaleler bu aşamada başlamıştır.

Üçüncü aşamada ise artık kapitalizmin evrensel rasyonelleri ile ulusal idealler çatışmaya başlamıştır. Bu aşamada, ulusal modernite projesinin, kendi mekanını üretme hedefi doğrultusundaki müdahaleleri, söz konusu kentlere liman kenti kimliği kazandıran bileşenlerde değişim yaratmıştır.

Ancak bu değişim, üç örnekte de farklı biçimlerde gerçekleşmiştir. Söz konusu değişim, Patras'ta güçlü yerel dinamiklerin etkisiyle, Volos'ta ulusal rasyonellerin güçlü etkisiyle ve Mersin'de, bağlamın irrasyonel yorumuyla farklı biçimlerde yaşanmıştır (Tablo 3). ${ }^{56}$

56 Ünlü, “On Dokuzuncu Yüzyıldan Yirminci Yüzyıla Doğu Akdeniz Liman Kentlerinde Mekanın Dönüşümü", 277-279. 
Dolayısıyla, en azından incelenen örnekler için, 19. yüzyıl sonundan 20. yüzyıl başına kadarki süreçte, söz konusu kentleri ortaklaştıran ve onlara "Doğu Akdeniz liman kenti" kimliği veren en önemli şey, Doğu Akdeniz coğrafyasında yaşanan kapitalist ekonomik ilişkilerle, geçirdikleri benzer değişim süreçleri olmuştur. Bu benzerlik, ortak bir kent kimliği üretmiş, ancak öte yandan yerelin kendine özgü koşulları, söz konusu kentlere kendine özgü bir karakter vermiştir.

Dolayısıyla, bu çalışma kapsamında incelenen üç kentten yola çıkıldığında, "Doğu Akdeniz liman kenti"ni üreten "ortaklıklar kümesi", temel olarak üç aşamalı olarak geçirdikleri benzer değişim süreci olurken, söz konusu kentleri kendine özgü kılan özellikler ise toplumsal yapıdan (burada Yunanistan ve Türkiye) ve mekânsal gelişim dinamiklerin kaynaklanan farklılıklar olmuştur.

\begin{tabular}{|c|c|c|c|c|}
\hline & AŞAMALAR & $\begin{array}{l}\text { DÖNEM } \\
\text { RASYONELLERi }\end{array}$ & $\begin{array}{l}\text { BÜYÜME } \\
\text { DINAMIKLERI }\end{array}$ & $\begin{array}{l}\text { MEKANSAL } \\
\text { GELiŞME }\end{array}$ \\
\hline \multirow{3}{*}{ 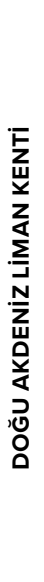 } & Birinci Aşama & $\begin{array}{l}\text { Kapitalizmin Evrensel } \\
\text { Birikim Beklentileri }\end{array}$ & $\begin{array}{l}\text { Liman Kenti Olarak } \\
\text { Ortaya Çıkış }\end{array}$ & $\begin{array}{l}\text { Spontane Mekânsal } \\
\text { Gelişim }\end{array}$ \\
\hline & İkinci Aşama & $\begin{array}{l}\text { Kapitalizmin } \\
\text { Uluslararası Mekânsal } \\
\text { Örgütlenmesinde } \\
\text { Uluslararası İttifaklar }\end{array}$ & $\begin{array}{l}\text { Benzer İktisadi } \\
\text { Süreçler ile } \\
\text { Benzeşerek } \\
\text { Gelişme }\end{array}$ & $\begin{array}{l}\text { Rasyonel Mekânsal } \\
\text { Müdahaleler }\end{array}$ \\
\hline & Üçüncü Aşama & $\begin{array}{l}\text { Evrensel } \\
\text { (Uluslararası)-Yerel } \\
\text { (Ulusal) Geriliminin } \\
\text { Artması }\end{array}$ & $\begin{array}{l}\text { Ulusal Modernite } \\
\text { ile Farklılaşma }\end{array}$ & $\begin{array}{l}\text { Güçlü Yerel } \\
\text { Dinamikler (Patras } \\
\text { Örneği) } \\
\text { İçselleştirilmiş Ulusal } \\
\text { Rasyoneller (Volos } \\
\text { Örneği) } \\
\text { Bağlamın İrasyonel } \\
\text { Yorumu (Mersin } \\
\text { Örneği) }\end{array}$ \\
\hline
\end{tabular}

Tablo 3. Doğu Akdeniz liman kentlerinin mekânsal gelişim rasyonel ve dinamikleri.

\section{Sonuç}

Çalışmada, iktisadi ve tarihi perspektifle ele alışların ötesinde, Doğu Akdeniz liman kentinin, farklı tarihsel süreçlerde yaşadığı değişimi, bu değişimin Doğu Akdeniz liman kenti kimliği ile ilişkisini ve bu kimliği üreten mekânsal yapıyı anlamak ve açıklamak hedeflenmiştir. Böylece, Doğu Akdeniz liman kentlerine ilişkin dünya sistemi analizine dayalı yaklaşımlara, ${ }^{57}$ yerelin etkisi üzerinde durarak bir katkı yapmak hedeflenmiştir. Doğu Akdeniz liman kentinin, içinde yer aldığı bağlam ve koşullara göre farklılaşıp farklılaşmadığını ya da ne tür benzerlikler taşıdığını araştırmak, merkez-çevre ilişkisine dair yeni bakışlara olanak yaratabileceği gibi, Doğu Akdeniz liman kentlerine ilişkin kuramsal ve tarihsel perspektife de katkı sağlayabilecektir. Bu doğrultuda, Doğu Akdeniz liman kenti olarak adlandırılan kentleri, mekânsal ya da yapısal bir belirlenimciliğin hâkim olduğu yaklaşımlara düşmeden ve söz konusu kentlerin kimliğini üreten iktisadi ve sosyal koşulları göz ardı etmeden, farklılıkları yaratan bağlamsal yönleri üzerinden tanımlayacak bir çerçeve oluşturulmaya çalışılmıştır.

57 Keyder, “Belle Epoque ve Liman Kentleri”, 17. 
Çalışmada, Doğu Akdeniz'de, geçmişte her üçü de birer Osmanlı limanı olan ve günümüzde Türkiye ve Yunanistan gibi iki farklı ülke sınırları içinde yer alan, Patras, Volos ve Mersin üzerinden yapılan inceleme ile bu kentlerde yaşanan kentsel değişim ve mekânsal yapı analiz edilerek kavramsal bir çerçeve sunulmuştur. Söz konusu çerçeve, incelenen üç örnekten yola çıkıldığında,

Akdeniz'in doğu kıyılarında, gelişimleri, tarımsal üretime dayalı uluslararası deniz ticaretinden ivme alan bu kentlerin, yerel ile küresel, ulusal ile uluslararası, içsel dinamikler ile dişsal süreçler arasındaki diyalektik ilişki çerçevesinde üç aşamada evrimleştiği;

Temelde tarihi ve iktisadi alanda yaşanan benzer gelişmelerin bu kentleri, benzer gelişim evreleri ve değişim süreçleri nedeniyle ortak bir kimlikle şekillendirdiği ve "Doğu Akdeniz liman kenti" olarak adlandırmalarını sağladığı;

Süreçlerdeki benzerliğin yanı sıra aktörler açısından da benzerlikler bulunduğu, bu kentlerde, azınlık ve komprador burjuvazinin etkili olduğu ticari etkinliğin söz konusu olduğu;

Bu kentlerin, ticari etkinliğin talep ve beklentileri ile iskele, liman, rihtım, demiryolu, postane, çeşitlilik gösteren uzmanlaşmış ticari etkinlik ve ticarethaneler, uluslararası ticari ilişkileri yürüten konsolosluklar gibi dönem kentlerinden farklılaşan benzer mekânsal kullanımlara sahip olduğu;

Deniz ticaretine dayalı ekonomileri ile bu kentlerin mekânsal gelişiminin, daima denizi (çoğu zaman kıyıdaki en büyük iskeleyi) referans alan bir kurguyla şekillendiği;

$\mathrm{Bu}$ kentlerde, ticari etkinlikle birlikte sınıfsal bir farklılaşmanın kendini gösterdiği, farklı nüfus gruplarının bulunduğu ve bunların kentsel mekânda yansımaları olarak, farklı nitelik ve mimari biçimlerde yapıların, farklı inançlara ait dini yapıların ve eğitim kurumlarının yer aldığı;

Bu kentlerin mekânsal yapılarının, kentin parçalarının ve parçalar arası ilişkilerin (eski şehir-yeni şehir, ticaret-konut bölgeleri ya da liman-demiryolu-karayolu gibi farklı ulaşım bağlantıları arasındaki ilişki) sürekli değişimine bağlı olarak devinim içinde olduğu, bu devinim ile parçalar arası ilişkinin oluşturduğu ilişkisel mekânsal kurgunun kendine özgü bir karakter ürettiği;

İlk evrelerinde, ticari etkinliğin gereklilikleri doğrultusunda, yerelin etkili olduğu, aşağıdan yukarıya bir gelişimle, herhangi bir plana dayalı olmadan "kendiliğinden" şekillenirken, sonraki aşamalarda (ulus-devlet süreçleri ile birlikte) planlı müdahalelerle geliştiği;

Söz konusu planların, yabancı uzmanlarca hazırlandığı ve temel olarak dönemin Batı'da uygulanan planlama yaklaşımlarını esas aldığı ancak, planı hazırlayan uzmanların formasyonları ve benimsedikleri ekoller ile yerin kendine özgü koşulları doğrultusunda farklılıklar gösterdiği;

Ortak kimliklerine karşın söz konusu kentlerin, özellikle 20. yüzyılın ikinci yarısından itibaren, yaşanan ulus-devletleşme süreçlerinin de etkisiyle, dönem rasyonelleri, büyüme dinamikleri ve içinde yer aldıkları bağlam (coğrafya, sosyal yapı vs.) doğrultusunda mekânsal gelişim ve biçimlenişlerinde farklılıklar oluştuğu görülmüştür.

İncelemenin esas aldığı dönem, özellikle Doğu Akdeniz coğrafyasının, kapitalist bütünleşme süreçleri içinde, küresel bir iş bölümünün parçası haline geldiği bir dönemdir. Ancak kapitalist ekonomiyle birlikte kendini göstermeye başlayan eşitsiz ekonomik ilişkiler bugün de tüm hızıyla varlığını sürdürmektedir. Bu nedenle kentlerin, yarışmacı ekonomik pazarların birer metası haline geldiği günümüzde, ticaretin sınırları aştığı birincil mekanlar olarak liman kentleri için, onlara kimlik ve karakter kazandıran süreç ve koşulları ortaya koymanın, bunların kentler üzerinde yarattığı/yaratacağı etkileri görebilmek için yararlı olacağı düşünülmektedir. 
Ancak elbette, söz konusu farklılık ve özgünlükler ile bunları üreten süreçleri anlamak/açıklamak için bu çalışmanın sınırları içinde elde edilen değerlendirme ve sonuçların, Akdeniz'deki başka liman kentleri için yapılacak benzer araştırmalarla karşılaştırılması ve zenginleştirilmesi büyük önem taşımaktadır.

\section{Kaynakça}

Annuaire Oriantal du Commerce. 1890.

Annuaire Oriantal du Commerce. 1889-1890.

Bakounakis, N. “19. Yüzyılda Patras'ın Sosyo-ekonomik Durumu”. Antik Dönemden Günümüze Patras içinde, derleyenler E. Sklavenitis, K. Staikos, 246-287. Atina: Kotinos, 2005 (Yunanca).

Benevolo, L. Avrupa Tarihinde Kentler. Çeviren Nur Nirven. İstanbul: Literatür, 2006.

Biray Kolluoğlu ve Meltem Toksöz, “Doğu Akdeniz'in Haritalandırması: Ticaret Kentleri Kartografyasına Doğru”, Osmanlılardan Günümüze Doğu Akdeniz Kentleri içinde, derleyenler Biray Kolluoğlu ve Meltem Toksöz, 1-16. İstanbul: Türkiye İş Bankası Kültür Yayınları, 2015.

Çelik, Zeynep. 19. Yüzyılda Osmanlı Başkenti Değişen İstanbul. Çeviren Selim Deringil. İstanbul: Tarih Vakfi Yurt Yayınları, 1998.

Dimoglou, A. ve L. Mourtzoukos. Volos then \& now. Atina: Olkos, 2006.

Blumi, İsa. "Doğu Akdeniz'e Yeni Tarihsel Ölçekler Eklemek: Yasadışı Ticaret ve Arnavut", Osmanlılardan Günümüze Doğu Akdeniz Kentleri içinde, derleyenler Biray Kolluoğlu ve Meltem Toksöz, 139-167. İstanbul: Türkiye İş Bankası Kültür Yayınları, 2015.

Dingeç, Emine. “19. Yüzyılın İkinci Yarısında ve 20. Yüzyılın Başında Mersin'in Ekonomik Yapısı". Yüksek Lisans Tezi, Anadolu Üniversitesi, 1998.

Driessen, H., "Mediterranean Port Cities: Cosmopolitanism Reconsidered". History and Anthropology 14, no. 1 (2005): 129-141.

Dokuz Eylül Üniversitesi, Şehir ve Bölge Planlama Bölümü. Habitat II Dünya Deneyimleri Kapsamında İzmir Bağlamına Nasıl Bakılabilir: Bir Gelişmenin Anatomisi. Yayınlanmamış Çalışma, İzmir, 1996.

Frangakis-Syrett, Elena. "Patras". Doğu Akdeniz'de Liman Kentleri (1800-1914) içinde, derleyenler Çağlar Keyder, Eyüp Özveren, Donald Ouataert, 23-34. İstanbul: Tarih Vakf1 Yurt Yayınları, 1994.

Fuhrmann, Malte ve Vangelis Kechriotis. "The Late Ottoman Port-Cities and Their Inhabitants: Subjectivity, Urbanity, and Conflicting Orders". Mediterranean Historical Review 24, no. 2, (2009): 71-78.

Gatopoulou, E. "Kentsel Planlama, Kentsel Altyapı, Mimarlık, Anıtlar (19 ve 20. Yüzy1llar)". Antik Dönemden Günümüze Patras içinde, derleyenler T. E. Sklavenitis ve K. Staikos, 288-317. Atina: Kotinos, 2005 (Yunanca).

Hastaoglou-Martinidis, Vilma, Kiki Kafkoula ve Nicos Papamichos. "Urban Modernization and National Renaissance: Town Planning in 19th Century Greece". Planning Perspectives 8, no. 4 (1993): 427-469.

Hastaoglou-Martinidis, Vilma. “Doğu Akdeniz Kentlerinde Liman İnşaatının Kartografyası: 19. Yüzyıl Sonunda Teknik ve Kentsel Modernleşme". Osmanlılardan Günümüze Doğu Akdeniz Kentleri içinde, derleyenler Biray Kolluoğlu ve Meltem Toksöz, 95-120. İstanbul: Türkiye İş Bankası Kültür Yayınları, 2015.

Hastaoglou-Martinidis, Vilma. Volos: Portrait of the City from the 19th Century to Today. Volos: DIKI, 2007 (Yunanca).

Hastaoglou-Martinidis, Vilma. "Foundation and Evolution of the New City During the 19th Century". Volos 1881-1955: The City and the People içinde, 43-60. Volos: DIKI, 2004.

Kasaba, Reşat. Dünya Imparatorluk ve Toplum: Osmanlı Yazıları. Çeviren M. Banu Büyükkal. İstanbul: Kitap Yayınevi, 2005.

House of Commons Parliamentary Papers, Report by Consul Thomas Wood, Trade of the Consular District of Patras, 1886, No: 78.

Indicateur Oriental. 1885-1886.

Katsiardi-Hering, Olga. "City-ports in the Eastern and Central Mediterranean from the Mid-sixteenth to the Nineteenth Century: Urban and Social Aspects". Mediterranean Historical Review 26, no. 2 (2011): 151-170. 
Keyder, Çağlar, Eyüp Özveren, Donald Quatert. “Osmanlı İmparatorluğu'nda Liman Kentleri: Bazı Kuramsal ve Tarihsel Perspektifler". Doğu Akdeniz'de Liman Kentleri (1800-1914) içinde, derleyenler Çağlar Keyder, Eyüp Özveren, Donald Ouataert, 121155. İstanbul: Tarih Vakfi Yurt Yayınları, 1994.

Keyder, Çağlar. "Belle Epoque ve Liman Kentleri”. Osmanlılardan Günümüze Doğu Akdeniz Kentleri içinde, derleyenler Biray Kolluoğlu ve Meltem Toksöz, 17-28. İstanbul: Türkiye İş Bankası Kültür Yayınları, 2015.

Kurmuş, Orhan. Emperyalizmin Türkiye'ye Girişi. İstanbul: Yordam, 2012.

Leontidou, Lila. The Mediterranean City in Transition: Social Change and Urban Development. New York: Cambridge University Press, 2006.

Lynch, Kevin. A Theory of Good City Form. Massachusetts: MIT Press, 1981.

Municipality of Patras. Haritalar ve Hatıralar 1813-1943. Patras: Patras Belediyesi, 2014 (Yunanca).

Norberg-Schulz, Christian. "The Phenomenon of Place”. Designing Cities: Critical Readings in Urban Design içinde, derleyen Alexander R. Cuthbert, 116-127. Malden, MA: Blackwell, 2006.

Osmanlı Şark Ticaret Yıllı̆̆ı. 1894.

Özveren, Eyüp. "Geçmişten Geleceğe Akdeniz Dünyası”. Akdeniz Uygarlıkları Sanatı içinde, derleyen Filiz Çalışlar Yenişehirlioğlu, 2-23. Eskişehir: Anadolu Üniversitesi Yayınları, 2012.

Pace, Giuseppe. "Ways of Thinking and Looking at the Mediterranean City". Munich Personal RePEc Archive (2002): 1-30. http://mpra.ub.uni-muenchen.de/10511.

Pallini, Cristina. “Doğu Akdeniz'de Coğrafi Tiyatrolar, Liman Peyzajları ve Mimari: Selanik, İskenderiye, İzmir". Osmanlılardan Günümüze Doğu Akdeniz Kentleri içinde, derleyenler Biray Kolluoğlu ve Meltem Toksöz, 73-94. İstanbul: Türkiye İş Bankası Kültür Yayınları, 2015.

Rother, L. Die Städte der Cukurova: Adana-Mersin-Tarsus. Tübingen: Geographisches Instituts der Universität Tübingen, 1971.

Simeonidou, A. "Pire, Volos ve Patras Limanları: Finansal Gelişim”. Yüksek Lisans Tezi, Kavala Teknolojik Eğitim Enstitüsü, 2015 (Yunanca).

Suher, Hande, Mehmet Ocakçı, Hatice Karabay Ayataç, Özhan Ertekin. "An Indicator of Sustainable Development: Urban Identity". A/Z ITU Journal of the Faculty of Architecture 1, no. 2 (2004): 26-42.

Tekeli, İlhan, “Türkiye'de Cumhuriyet Döneminde Kentsel Gelişme ve Kent Planlaması”. 75 Yılda Değişen Kent ve Mimarlık içinde, derleyen Yıldız Sey, 1-24. İstanbul: Tarih Vakfı Yurt Yayınları, 1998.

Tekeli, İlhan. “19. Yüzyılda İstanbul Metropol Alanının Dönüşümü”. Modernleşme Sürecinde Osmanl Kentleri içinde, derleyenler Paul Dumont ve François Georgeon, 19-30. İstanbul: Tarih Vakfı Yayınları, 1999.

Ünlü, Tolga ve T. Levent. “Mersin'de Kentsel Mekanın Biçimlenmesinde Jansen Planı'nın Etkileri". Tarih İçinde Mersin Kolokyum II içinde, derleyen Tülin Selvi Ünlü, 160-175. Mersin: Mersin Üniversitesi, Akdeniz Kent Araştırmaları Merkezi Yayınları, 2005.

Ünlü, Tolga. "Mekansal Planlamanın Kentin Biçimlenmesine Etkisi: Mersin Örneği". Planlama 2009, no. 3-4 (2009): 27-42.

Ünlü, Tülin Selvi. “19. Yüzyılda Mersin'in Kentsel Gelişimi”. Yüksek Lisans Tezi, Mersin Üniversitesi, 2007.

Ünlü, Tülin Selvi. “On Dokuzuncu Yüzyıldan Yirminci Yüzyıla Doğu Akdeniz Liman Kentlerinde Mekanın Dönüşümü: Volos, Patras ve Mersin”. Doktora Tezi, Dokuz Eylül Üniversitesi, 2016.

Wagstaff, Malcolm ve Elena Frangakis-Syrett. "The Port of Patras in the Second Ottoman Period: Economy, Demography and Settlements c. 1700-1830". Revue des mondes musulmans et de la Méditerranée 66, no. 1 (1992): 79-94.

Waite, James. "The Railways of Volos". The International Steam Pages. http://www.internationalsteam.co.uk/trains/greece02.htm, erişim tarihi 14 Mart 2016.

Yenişehirlioğlu, Filiz. "Urban Texture and Architectural Styles After the Tanzimat". Economy and Society on Both Shores of the Aegean içinde, derleyenler Lorans Tanatar Baruh ve Vangelis Kechriotis, 487-526. Atina: Alpha Bank, 2010. 